\title{
Should Regulators Set Rates to Terminate Calls on Mobile Networks?
}

\author{
Robert W. Crandall ${ }^{\dagger}$ \\ J. Gregory Sidak ${ }^{\dagger \dagger}$
}

When a person uses the traditional wireline telephone network to call another person on his cell phone, the fixed network must transfer the call to the mobile network to which the recipient subscribes. The fixed network provides originating access for the call, and the mobile network provides terminating access. This paper provides an economic analysis of the regulation of fixed-to-mobile termination rates. Mobile party pays ("MPP") creates better incentives than calling party pays ("CPP") for mobile network operators to place downward pressure on termination rates. Cellular telephone use in the United States and Canada has continued to increase at a significant pace despite the MPP regime and now far exceeds mobile telephone use in countries with CPP regimes.

Multiple factors, including substitution possibilities for the callers of mobile subscribers, constrain the market power of mobile operators in setting mobile termination rates under CPP regimes. It is unrealistic for regulators to attempt to set mobile rates, including termination rates, at marginal cost. If large fixed network costs and customer acquisition costs must be recovered from variable charges, then marginal-cost-based pricing is not feasible. Also, the value to callers of being able to reach mobile subscribers justifies mobile termination charges that exceed marginal cost because of network externalities in mobile telecommunications. Finally, mobile termination rates that exceed marginal cost (or its proxy, long-run average incremental cost) are consistent with Ramsey (quasi-efficient) pricing. To the extent that high termination rates are a problem in countries that have embraced CPP, it is because customers are poorly informed of the charges they pay for their terminating calls. Consumer education would solve the potential market failure without the need to impose price regulation on otherwise competitive markets.

Introduction 263

I. The Global Movement To Regulate Mobile Termination Rates .....266

A. The Theory That CPP Gives MNOs Market Power over Mobile Termination Rates.

B. Examples of Countries That Have Embraced the

$\dagger \quad$ Senior Fellow, The Brookings Institution.

it F.K. Weyerhaeuser Fellow in Law and Economics Emeritus, American Enterprise Institute for Public Policy Research. We thank Nigel Attenborough, Richard Feasey, Keiko Hatta, Charles L. Jackson, David Jeppsen, Jean Le Roux, Makoto Kojo, Tasuruhiko Nambu, Reinhard Schu, Hal J. Singer, Leonard Waverman, and Takao Yoshida for comments and Christopher Bowen and Brian O'Dea for research assistance. The views expressed here are solely those of the authors and not those of the Brookings Institution or the American Enterprise Institute, neither of which takes institutional positions on specific legislative, regulatory, adjudicatory, or executive matters. 


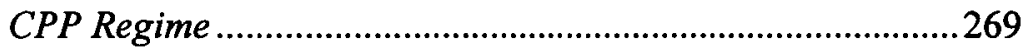

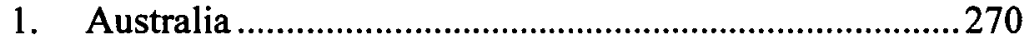

2. United Kingdom........................................................271

3. European Commission ....................................................274

4. Other National Regulatory Authorities and

National Competition Authorities within the

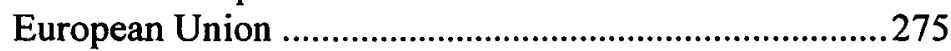

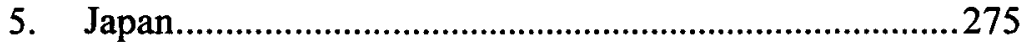

6. Summary of Regional Regulatory Initiatives...................277

C. The Federal Communications Commission and

U.S. Trade Representative's Support for

Regulation of Mobile Termination Rates Outside

the United States

D. Both Parties Pay for Mobile Calls in the United

States

1. MPP and Reciprocal Compensation

Agreements Obviate the Regulation of

Mobile Termination Rates.

2. Cellular Telephone Use Continues To

Increase Significantly in the United States

and Canada

II. Forces That Constrain an MNO's Market Power ...........................286

A. Demand Substitutes for Fixed-to-Mobile Calls........................286

1. Mobile-to-Mobile Calls.................................................286

2. Mobile-to-Fixed Calls ...................................................288

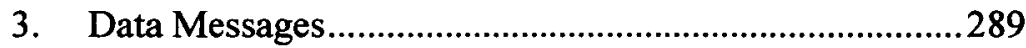

4. Fixed-to-Fixed Calls...................................................290

5. Routing Fixed-to-Mobile Calls Through

Mobile Networks..........................................................2290

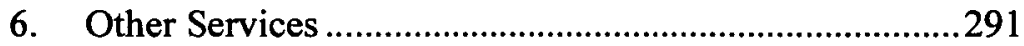

B. The Effect of Termination Rates on the

Subscriber's Inbound Calls...................................................291

C. Closed User Groups: Mobile Customers ' Concern for the Welfare of Their Callers ............................................293

D. Supply Substitution................................................................295

E. The Effect of Mobile Affiliation with a Fixed

Network.

F. Summary of Forces That Constrain an MNO's

Market Power.

III. If Market Failure Is Thought To Exist in Fixed-to-Mobile

Termination, Are Price Controls the Socially Optimal

Remedy? 
A. The Recovery of Large Fixed Network Costs and Customer Acquisition Costs Through Variable Charges

B. The Role of Network Externalities in Mobile Telecommunications

C. Termination Rates as Part of Ramsey (QuasiEfficient) Pricing

D. The Pitfalls of TELRIC-Style Regulation ..................................303

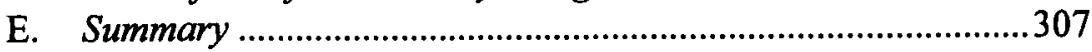

IV. The Lower Social Cost of Market-Based Solutions.

A. Mandatory Disclosure of Termination Rates to Customers of Fixed Networks 307

B. Imposition of Dedicated Number Prefixes for Mobile Operators 308

C. Mandatory Disclosure of Termination Rates to Mobile Customers Upon Activation of Account 309

D. Elimination of Regulation of Mobile-to-Fixed Termination Rates 309

V. Conclusion

Introduction

When a person uses the traditional wireline telephone network to call another person on his cell phone, the fixed network must transfer the call to the mobile network to which the recipient subscribes. The fixed network provides originating access for the call, and the mobile network provides terminating access. In the United States, the recipient pays for mobile termination-an arrangement called "mobile party pays," or MPP. Other countries, however, employ "calling party pays," or CPP." The person calling from the fixed network will not necessarily know beforehand the identity of the mobile carrier that will be terminating his call, and thus under CPP the caller will not necessarily know the price that he will be charged for fixed-to-mobile termination. As a consequence, a policy debate has arisen over whether a market failure exists, because it is alleged that competitive forces do not constrain fixed-to-mobile termination rates under a regime of CPP. This debate has taken place, or is actively occurring, in Australia, Europe, Asia, and North America.

Several noted telecommunications economists have studied mobile termination rates. In defense of the MPP system used in the United States, Professor Jerry Hausman of the Massachusetts Institute of Technology

1 Under CPP, the receiver will usually pay something for an incoming call, but the receiver will not pay the incremental cost of termination. 
notes that the growing popularity of "bucket plans," which offer a large number of incoming and outgoing minutes at a fixed price, has tempered U.S. customers' reluctance to disclose their mobile telephone numbers. ${ }^{2}$ Hausman argues that, to the extent there is a problem of high termination rates in countries that have embraced CPP, it is because customers are ignorant of the charges they pay for their terminating calls. ${ }^{3} \mathrm{He}$ concludes that "consumer information would solve the potential market failure problem without the need for regulatory interference in competition . ..."4 Professor Julian K. Wright of the University of Auckland shows that above-cost termination rates result in low cellular prices (per minute) and high penetration rates because of competition among mobile carriers to sign new customers. ${ }^{5} \mathrm{He}$ finds that significant margins on access prices do not imply that access charges are set too high from a welfare perspective. ${ }^{6}$ He suggests allowing the fixed-line network operator to set differential prices to reflect different cellular termination rates and allowing the fixedline network operator to negotiate its own termination rates with the MNOs freely: "As long as the firms' bargaining power is roughly balanced, the tendency for cellular firms to set high termination charges may be alleviated."?

Professor James Mirrlees of the University of Cambridge explains that the welfare gains that could be realized by a move toward regulation of mobile call termination rates are modest at best. ${ }^{8}$ Mirrlees estimates that the annual welfare increase would be roughly one-tenth the size of the benefits upon which the U.K.'s Competition Commission relied in justifying its price cap on mobile termination rates $(£ 4.7$ million versus $£ 54.5$ million). ${ }^{9}$ He argues that the Commission failed to understand the manner in which mobile operators stimulate mobile subscriptions and increase welfare in the unregulated scenario by lowering other mobile rates when they increase mobile termination rates. Professor Stephen Littlechild of the University of Cambridge also provides a critique of the U.K.'s Office of Telecommunications ("Oftel's") approach to regulation of

2 Jerry A. Hausman, Mobile Telephone, in 1 HANDBOOK OF TELECOMMUNICATIONS ECONOMICs 564, 595 (Martin Cave, Sumit K. Majumdar, \& Ingo Vogelsang eds., 2002).

$3 \quad$ Id. at 596.

$4 \quad$ Id.

5 Julian K. Wright, Access Pricing Under Competition: An Application to Cellular Networks, 50 J. INDUS. ECON. 289 (2000).

$6 \quad$ Id. at 309.

7 Id. at 314.

8 Witness Statement of James Alexander Mirrlees, In the High Court of Justice Queen's Bench Division Administrative Court, Between The Queen, on the Application of Vodafone Limited and the Competition Commission and the Director General of Telecommunications, 2003 EWHC 1555, I 152, [2003] All E.R. 377 (Q.B. Mar. 5, 2003), available at http://www.courtservice.gov.uk/judgmentsfiles/j1826/mobiles.htm. 
mobile termination rates. ${ }^{10}$ Littlechild argues that, given the dynamic nature of the mobile industry, remedies should focus more on promoting entry and less on imposing price controls. ${ }^{11}$ These and other economists oppose regulation of fixed-to-mobile termination rates. ${ }^{12}$

Other economists favor regulating mobile termination rates. For example, Professor Mark Armstrong of Oxford University argues that "even though networks compete vigorously for subscribers, they often have a monopoly position in providing communications services to their subscribers." ${ }^{13}$ He argues that carriers under CPP earn monopoly rents from termination rates and use them to subsidize retail tariffs offered to attract subscribers. ${ }^{14}$ Armstrong advocates regulation of mobile termination rates at marginal cost plus a factor that accounts for network externalities. ${ }^{15}$

This Article provides an economic analysis of fixed-to-mobile termination rates. In Part I, we survey the regulatory policies involving mobile termination that various governments and international bodies have considered and even adopted. We explain why MPP creates better incentives than CPP for mobile network operators ("MNOs") to decrease mobile termination rates. We provide a brief history of the U.S. experience with MPP. There is no need to regulate mobile termination rates in the United States or Canada because regulators in both countries have shunned CPP. Finally, we demonstrate that minutes of cellular telephone use in the United States and Canada have continued to increase at a significant pace despite the MPP regime and are greater than in countries with CPP regimes.

In Part II, we examine whether MNOs have market power in the provision of terminating access to mobile networks. We examine demand substitution for fixed-to-mobile calls, a consideration that has received surprisingly little attention to date in the debate over mobile termination

10 S.C. Littlechild, Regulators, Competition, and Transitional Price Controls: A Critique of Price Restraints in Electricity Supply and Mobile Telephones (Feb. 20, 2002) (unpublished manuscript, on file with the Yale Joumal on Regulation), available at http://www.iea.org.uk/record.jsp?type=article\&ID=38. Oftel's approach involves analyzing the return on capital achieved by mobile operators. $I d$. at 80 .

$11 I d$. at 5.

12 See, e.g., David Newbery, Vodafone Limited, Regulating Mobile Call TERMINATION (July 18,2003 ) (arguing that there is a case for subsidizing mobile subscriptions relative to incremental cost because new mobile subscribers confer a network externality on existing mobile and fixed line subscribers, which new mobile subscribers will undervalue in making the subscription decision). See also Christopher Doyle \& Jennifer C. Smith, Market Structure in Mobile Telecoms: Qualified Indirect Access and the Receiver Pays Principle, 10 INFO. ECON. \& POL'Y 471 (1998).

13 Mark Armstrong, The Theory of Access Pricing and Interconnection, in 1 HANDBOOK OF Telecommunications Economics 295, 337 (Martin Cave, Sumit K. Majumdar, \& Ingo Vogelsang eds., 2002) (emphasis in original).

14 Id.

15 Id. at $341-43$. 
rates. We also consider how the joint demand of the calling party and the receiving party constrains mobile termination rates. When mobile customers even partially internalize the welfare of their callers, as they could be expected to do for family or business associates, the economic justification for regulating mobile call termination in a competitive market greatly diminishes.

In Part III, we explain why mobile rates, including termination rates, cannot and should not be equal to marginal cost. In particular, MNOs typically recover large fixed network costs and customer acquisition costs from variable charges. Next, we explain why network externalities in mobile telecommunications justify mobile termination rates that exceed marginal cost. We explain how mobile termination rates that exceed marginal cost are consistent with Ramsey (quasi-efficient) pricing. Finally, we show that regulation of fixed-to-mobile termination rates at marginal cost (or even slightly higher to account for network externalities) would not be socially optimal.

In Part IV, we show that, compared with price regulation of mobile termination rates, a number of other policy measures would be more efficacious in remedying any market failure that regulators believe exists on the ground that consumers currently lack complete information about mobile termination rates. The simplest rule would require, through a "ping" or brief recorded message, the identification of the mobile carrier that is about to complete a call originating on the fixed network. Other possible rules include mandatory public disclosure of mobile termination rates and the substitution of negotiation for regulation of mobile-to-fixed termination rates.

\section{The Global Movement To Regulate Mobile Termination Rates}

Mobile termination is not an issue in the United States because the United States has rejected a CPP regime. In nations that have embraced $\mathrm{CPP}$, regulators have examined the rates that MNOs charge to terminate calls on their networks. For example, the United Kingdom's former telecommunications regulator, Oftel, imposed price regulation on mobile termination, and the Competition Commission has investigated the matter at length. The Competition Directorate of the European Commission ("DG Competition") is actively considering price regulation. ${ }^{16}$ In Japan, the government has examined the question of mobile termination rates but has

16 A study group of the International Telecommunications Union ("ITU") has recommended price regulation. See INT'L TELECOMMS. UNION, TELECOM STANDARDIZATION RECOMMENDATION D.150, $\S 2.5 .2$ (June 1999) (requiring mobile termination rates to be "cost orientated, separately identified and bilaterally available at http://www.itu.int/osg/spu/ni/fmi/approach/ITU_D150.doc. 
taken no action. In the United States, the Federal Communications Commission ("FCC") and the U.S. Trade Representative ("USTR") have tried to influence, if not explicitly regulate, mobile termination rates in other countries through American telecommunications legislation and U.S. trade policy. After we present the theory that CPP gives mobile network operators market power over mobile termination rates, we discuss developments in each of these jurisdictions.

\section{A. The Theory That CPP Gives MNOs Market Power over Mobile Termination Rates}

By subscribing to an MNO's mobile telephone service, the subscriber purchases a bundle of service offerings. The provision of mobile services consists of three major components: (1) call origination, which allows a mobile subscriber to call his own mobile network (known as "on-net" calls) or other mobile and fixed-line networks ("off-net" calls); (2) call termination, which allows a mobile subscriber to receive a mobile call; and (3) value-added services such as short message services ("SMS") or information services. ${ }^{17}$ The MNO derives revenue from each of these services. Under both MPP and CPP, the MNO collects charges for outgoing call services and value-added services from its mobile subscribers. Under a CPP regime, the MNO collects access charges for termination services (mobile termination rates) from the caller's network, which in turn collects the charges from the caller. ${ }^{18}$ Under an MPP regime, by contrast, the MNO collects termination charges from the caller's fixed network and from the mobile subscriber receiving the call. Figure 1 summarizes the payments of mobile termination rates.

17 See, e.g., BLUE SKY TELECOM SOLUTIONS, White PAPER: INTERCONNECTION SERVICES 3-7 (2003) available at http://www.bstsolutions.co.uk/whitepapers/ BSTS\%20Whitepaper_Interconnection\%20Services.pdf; Press Release, SoloMio, SoloMio To Showcase Power of Smart Call Services Platform at Parlay Conference in San Diego, May 20, 2003, available at http://www.solomio.com/news/20may03_ pr/0,1193,00.html (stating that SoloMio valueadded services "enable Mobile Operators to increase call origination, call termination, and message origination").

18 For a brief description of the different services and revenue streams under a CPP regime, see Austl. COMPETITION \& CONSUMER COMM'N, PRICING METHOdOlOgY FOR THE GSM TERMINATION SERVICE 25-26 (July 2001), available at http://www.accc.gov.au/content/ index.phtml/itemId/341564 [hereinafter ACCC 2001 STUDY]. 
Figure 1: Payments of Mobile Termination Rates

\section{Under CPP and MPP}

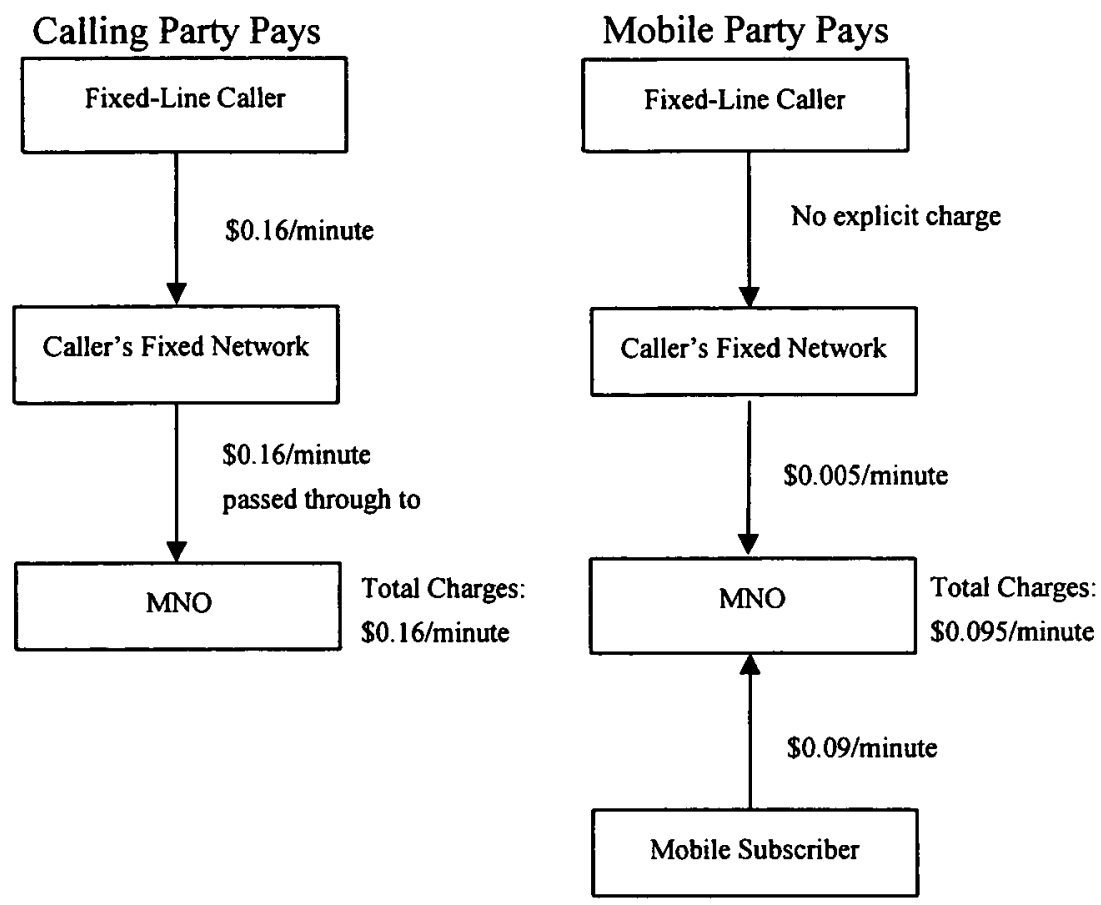

As Figure 1 shows, under a CPP system, the MNO bills the caller's network $\$ 0.16$ per minute ${ }^{19}$ in this hypothetical example. The caller's network ultimately passes that charge along to its customer. Under an MPP system with reciprocal compensation, ${ }^{20}$ the $\mathrm{MNO}$ charges the caller's network $\$ 0.005$ per minute ${ }^{21}$ and deducts one minute of service from the mobile subscriber's bucket of minutes. If the subscriber uses his exact allotment of minutes per month, the average cost of receiving the call is $\$ 0.09$ per minute ${ }^{22}$ in this example. So, the MNO implicitly embeds the

19 This rate is the average fixed-to-mobile termination rate per minute among Western European MNOs, according to the FCC. See Annual Report and Analysis of Competitive Market Conditions with Respect to Commercial Mobile Services, 18 F.C.C.R. 14,783 \ 207 (2003) [hereinafter FCC Eighth Annual Report].

20 Reciprocal compensation refers to the payments made between telecommunications carriers for terminating each other's local exchange traffic on their networks.

21 This rate is the average fixed-to-mobile termination rate per minute among U.S. MNOs, according to the FCC. Id. ๆ 207

22 This rate is the average rate per minute for Sprint PCS customers who select the 500minute-per-month plan. See Sprint, Sprint PCS Free \& Clear Nationwide, at http://www.pcsvision.com/NVP-

Online/plans/nationwide.html? $\mathrm{cn}=\& \mathrm{mrc}=\& \mathrm{phone}=\& \mathrm{acces}=\& \mathrm{ts}=\& \mathrm{rep}=\& \mathrm{st}=0 \& \mathrm{sb}=0 \& z=$ (last visited 
$\$ 0.005$ per minute in the price per minute (if any) that it charges its subscriber. Under U.S. practice, each network pays the other for calls that it sends to the latter's network. The fixed network does not pass these charges on to the caller, but it receives $\$ 0.005$ per minute for calls sent to it by the MNO.

The generally perceived consequence of this revenue structure is that MNOs have an incentive to keep the price of those services required and paid for by the mobile subscriber at a level that is low enough to attract and retain customers. But, MNOs have less incentive to minimize the price of terminating calls from non-subscribers. ${ }^{23}$ To the extent that mobile customers do not fully internalize the costs incurred by fixed-line customers who call them, competition among MNOs in a CPP regime will not bring mobile termination rates in line with marginal cost. Because mobile subscribers pay only for the calls they make under CPP, the theory goes, competition among MNOs to attract and retain customers exerts downward pressure on the price of outgoing mobile calls but not on mobile termination rates. This theory of "caller exploitation" presumes that fixedline callers have little choice but to terminate their calls on the mobile subscriber's network.

\section{B. Examples of Countries That Have Embraced the CPP Regime}

Several countries have embraced CPP and the associated regulation of mobile termination rates. Presumably, regulators in those countries have accepted the theory that CPP confers market power on mobile operators and leads to the exploitation of callers from fixed networks. For example, the Organization for Economic Cooperation and Development ("OECD") has stated that in CPP countries "there will be little competitive pressure on fixed-to-mobile termination charges," a situation that the OECD believes will lead to supracompetitive rates. ${ }^{24}$ The OECD recommended that its member governments regulate fixed-to-mobile termination rates if the rates have been persistently high. ${ }^{25}$

The International Telecommunications Union ("ITU") has also recommended that national regulatory authorities ("NRAs") regulate mobile termination rates. ${ }^{26}$ In 2003 , the ITU suggested that, in the absence

\footnotetext{
Apr. 17, 2004).

23 For a concurring view, see OfTEL, REVIEW OF THE CHARge CONTROL ON CALlS to MOBILES 44 (Sept. 26, 2001), available at http://www.ofcom.org.uk/static/archive/oftel/publications/mobile/ctm0901.pdf [hereinafter OFTEL STUDY].

24 ORg. FOR ECON. COOPERATION \& DEV., COMPETITION AND REgUlation ISSUES IN TELECOMMUNICATIONS 9 (Feb. 1, 2002).

25 Id. at 33.

26 Valerie feldman, itu Strategy and Policy Group, Mobile OVertakes Fixed: IMPLICATIONS FOR POLICY AND REGULATION $\S 6.2 .2$ (June 2003), available at
} 
of price controls, consumers lack bargaining power vis-à-vis MNOs in CPP countries. ${ }^{27}$ In addition, the ITU explained that international mobile termination rates require special attention because of the additional need for interconnection agreements between countries. ${ }^{28}$ The ITU recommended that NRAs either impose price controls or increase competition through encouraging the development of mobile virtual network operators ("MVNOs"). ${ }^{29}$ Although the ITU acknowledged that consumers in MPP countries pay lower termination rates than consumers in CPP countries, it reasoned that MPP reduces mobile access and is not socially desirable. ${ }^{30}$

In this section, we review the initiatives of several NRAs (and the European Union) concerning fixed-to-mobile termination rates.

\section{Australia}

The Australian Competition and Consumer Commission ("ACCC") articulated its initial position on mobile termination rates in its report, Pricing Methodology for the GSM Termination Service, issued in July $2001 .^{31}$ In its Mobile Services Review 2003 Discussion Paper, the ACCC found that mobile termination rates in Australia were "not at excessively high levels by international standards. ${ }^{332}$ The ACCC noted that it would continue to regulate termination rates for global system mobile communications ("GSM") and code division multiple access ("CDMA") services as long as regulation (1) promoted competition, (2) increased connectivity, and (3) produced economically efficient investments in the technology. ${ }^{33}$ The ACCC chose to continue regulating mobile termination

http://www.itu.int/osg/spu/ni/mobileovertakes/Resources/Mobileovertakes_Paper.pdf.

27 Id. \$ 6.1.2.

$28 \quad$ Id. $\S 6.2 .2$

29 Id. MVNOs are networks that provide cellular service by leasing frequency from cellular network operators. They are typically well-known brands that repackage bandwidth and give the impression of being cellular network operators by offering unique services and/or calling plans. For example, Virgin Mobile, resells Sprint cellular services in the United States to youth through prepaid calling plans.

$30 \quad$ Id. $\$ 2.1 .2$.

31 ACCC 2001 STUDY, supra note 18. The ACCC confirmed its position in two subsequent decisions. See AUSTL. COMPETITION \& CONSUMER COMM'N, PRICING METHODOLOGY FOR THE GSM AND CDMA TERMINATION SERVICES (June 2002), available at http://www.accc.gov.au/content/item.phtml?itemId=341518\&nodeld=file3f24a2985b0ed\&fn=Pricing $\% 20$ Methodology\%20for\%20the\%20GSM\%20and\%20CDMA\%20Termination\%20services $\% 20$ $\% 20$ Draft\%20Report.pdf; AUSTL. COMPETITION \& CONSUMER COMM'N, VARIATION TO MAKE THE GSM SERVICE DECLARATIONS TECHNOLOGY-NeUTRAL (Mar. 2002), available at http://www.accc.gov.au/content/index.phtml/itemId/378914/fromItemId/269262.

32 Austl. COMPETITION \& CONSUMER COMM'N, MOBILE SERVices REVIEW 2003 DISCUSSION PAPER 34 (Apr. 2003), available at $\mathrm{http}: / / \mathrm{www}$.accc.gov.au/content/item.phtml?itemId=397852\& nodeld=file3fadd74b2d9cc\&fn=Disc\%2 OPaper_Mobile\%20Serv\%20Review_Apr03.pdf.

$\overline{3} 3 \quad$ Id. at 6-7. 
rates on the rationale that an MNO controls access to mobile termination and the public lacks knowledge about mobile termination rates, which allows an MNO to raise prices without fear of competition. ${ }^{34}$ The ACCC also invited comments on whether it should keep a regulatory scheme for mobile termination that compared changes in the mobile termination rate to changes in the MNO's retail price. ${ }^{35}$ The ACCC noted that, despite its imposition of retail-to-wholesale benchmarking on MNOs in 2001, mobile termination rates may have increased. ${ }^{36}$

Numerous parties responded to the ACCC's request for comment. For example, MCI and AAPT (the wireless subsidiary of Telecom New Zealand), which both had attempted unsuccessfully to enter the Australian mobile telephony market in 2001, asked the ACCC to lower mobile termination rates to European levels. ${ }^{37}$ Telstra and other MNOs argued that no Australian MNO could exercise market power because of intense competition and that the ACCC had no evidence that any MNO was earning economic rents from its mobile termination rate. ${ }^{38}$ The MNOs further argued that lowering the mobile termination rate would result in higher usage fees for mobile customers. ${ }^{39}$ The ACCC announced its intention to release a draft report by September of 2003, with a goal of issuing its final report by the end of 2003. As of October 2003, the ACCC had not released its draft report.

\section{United Kingdom}

The major U.K. MNOs-BT Cellnet, One2One, Orange, and Vodafone-opposed regulation of mobile termination rates by the Office of Telecommunications ("Oftel"). In December 2000, these MNOs submitted an economic report to Oftel by David Newbery of Cambridge University, Raquel Noriega of the consultancy LECG, and Leonard Waverman of London Business School. Newbery, Noriega, and Waverman explained that MNOs had little incentive to raise mobile termination rates because doing so would discourage calls to mobile

$34 \quad$ Id. at 31.

35 Id. at 39.

$36 \quad$ Id. at 49.

37 MCI, COMMENTS OF MCI REgARDING THE AUSTRALIAN COMPETITION AND CONSUMER COMMISSION DISCUSSION PAPER ON MOBILE SERVICES REVIEW 2003, at 4 (June 13, 2003), available at http://www.accc.gov.au/content/item.phtml?itemld=397880\&nodeld=file3ffa39f97b45e\&fn $=\mathrm{MCl} \% 20$ Inc.pdf.

38 TElstra, INITIAL RESPONSE to THE Discussion PAPER OF tHE AUSTRALIAN COMPETITION AND CONSUMER COMMISSION 3 (Apr. 2003), available at http://www.accc.gov.au/content/item.phtml?itemId=444056\&nodeld=file4062658c91 e6c\&fn=Telstral .pdf. 
networks and decrease overall profits. ${ }^{40}$ Oftel rejected these arguments on the grounds that they did not explain how an increasing number of MNOs would drive down the mobile termination rate or how soon the rates would fall. ${ }^{41}$ In May 2001, the U.K. MNOs submitted a second report to Oftel by these same economists, which argued that mobile termination rates should exceed marginal cost to allow MNOs to recover the fixed costs of the network, such as mobile towers and licenses. ${ }^{42}$ Oftel rejected this argument, reasoning that the MNOs had failed to demonstrate that their termination rates were at an efficient level to recover fixed costs and that nothing prevented the MNOs from raising prices above the efficient level in the absence of regulation. ${ }^{43}$

In September 2001, Oftel "recommended" that MNOs in the United Kingdom decrease their termination rates by twelve percent per year to bring the rates down to roughly $\$ 0.06$ per minute. ${ }^{44}$ Three large MNOs contested the recommendation, and Oftel referred the matter to the Competition Commission for a determination of whether the firms' mobile termination rates reflected a competitive marketplace and, if not, what the appropriate remedy should be. ${ }^{45}$

In its Remedies Letter and Statement of July 2002, the Competition Commission emphasized that the MNOs charged mobile termination rates that exceeded the reasonable estimates of "true cost." expressed concern that the subsidy paid by fixed-line users represented a market distortion. ${ }^{47}$ The Competition Commission agreed with Oftel that a price cap would provide the best regulation for fixed-to-mobile termination rates, reasoning that price caps would force prices lower while allowing MNOs to vary termination rates efficiently. ${ }^{48}$ Although the Commission briefly considered switching to an MPP system as a remedy, it evidently did so only to invite further comments. ${ }^{49}$ Finally, although the

40 David Newbery, Raquel Noriega, \& Leonard Waverman, LECG, The Economics of Mobile Call Termination (Dec. 12, 2000).

41 OFTEL STUDY, supra note 23, at 58-59.

42 David Newbery, Raquel Noriega, \& Leonard Waverman, LECG, Efficient Pricing of Mobile Call Termination, LRIC Examined.

43 OFTEL STUDY, supra note 23, at 80.

44 Id. Oftel's action was technically a "recommendation" rather than an order because Oftel could not enforce the regulation without an order from the Competition Commission. In the past, the MNOs had agreed to Oftel's recommendations on pricing.

45 See UK Oftel Refers Operators to Competition Commssion That Could Threaten $3 G$ Rollout, 3GNEWSROOM.COM, Dec. 12, 2001, at http://www.3gnewsroom.com/3g_news/dec_01/news_1610.shtml.

46 COMPETITION COMM'N, MOBILE PHONES INQUIRY: STATEMENT OF HYPOTHETCIAL REMEDIES 7 (July 23, 2002), available at http://www.competitioncommission.org.uk/press_rel/archive/2002/jul/pdf/39-02rem.pdf. The phrase "true cost" is used frequently by Oftel but is never defined.

47 Id.

48 Id. at 10.

49 Id at 12. 
Commission acknowledged that the regulation of fixed-line termination rates gives MNOs a competitive advantage vis-à-vis fixed-line operators, the agency did not consider deregulation of fixed-line termination rates to be a viable remedy. ${ }^{50}$

In January 2003, the Competition Commission completed its inquiry into mobile termination rates and authorized Oftel to order the two largest MNOs, Vodafone and $\mathrm{mm} 02$, to decrease their rates by fifteen percent by July 2003 and then by fifteen percent per year thereafter until March 31, $2006 .{ }^{51}$ Oftel also ordered the third and fourth largest MNOs, Orange and T-Mobile, to decrease their termination rates by fourteen percent by July 2003 and then by fourteen percent per year until March 31, 2006. ${ }^{52}$

In June 2003, Orange, T-Mobile, and Vodafone appealed Oftel's decision to the Administrative Court of the High Court of Justice, but the High Court affirmed the regulator's decision. ${ }^{53}$ Vodafone, Orange, and TMobile then notified customers that, to compensate for the decrease in revenues from lower mobile termination rates, the MNOs would raise the prices of handsets, outgoing calls, and text messaging. ${ }^{54}$ In addition, the companies warned that the ordered reduction in mobile termination rates would delay the introduction of third-generation (3G) data services, with mm02 announcing that it would delay the implementation of nextgeneration phones until late 2004. ${ }^{55}$ In September 2003, Vodafone, Orange, T-Mobile, and $\mathrm{mm} 02$ challenged Oftel's authority to mandate future rate reductions, arguing that only Ofcom, the new regulatory commission created by the Communications Act of $2003,{ }^{56}$ could promulgate future rules on mobile termination rates. The MNOs also argued that the future price reductions imposed by Oftel in January 2003 were not legally binding. ${ }^{57}$ As of October 2003, the High Court of Justice had not decided the case.

Oftel had considerable influence with other European NRAs, and it is

50 Id. at 5 (asserting that MNOs "appear to enjoy a competitive advantage over the FNOs [fixed network operators], whose termination charges to MNOs and retention on calls from mobiles are effectively regulated to levels at or near cost").

51 OFTEL, REPORTS ON REFERENCES UNDER SECTION 13 OF THE TELECOMMUNICATIONS ACT 1984 ON THE CHARGES MADE BY VODAFONE, O2, ORANGE AND T-MOBILE FOR TERMINATING CALLS FROM FIXED AND MOBILE NETWORKS \$§ 1.12(a)-(d) (Jan. 22, 2003), available at http://www.competition-commission.org.uk/rep_pub/reports/2003/fulltext/475cl .pdf.

$52 \quad$ Id.

53 T-Mobile, Ltd. v. Competition Comm'n, [2003] A.C.D. 72 (Q.B. Admin. Ct. 2003).

54 Sean Poulter, Mobile Firms Plan 700M Revenge for Cheaper Call Costs, DAILY MAIL, June 28, 2003, at 13, available at 2003 WL 63928004.

55 Joel Cooper, Price Controls Will Impact on $3 G$ Roll-Out, Says mmO2 CEO, WMRC DAIl Y ANALYSIS, Oct. 10, 2002, available at 2002 WL 106431289; Press Release, mm02, Preliminary Results for the 12 Months Ended 31 March 2003, REg. NEws SERVICE, May 21, 2003, available at 2003 WL 55379448.

56 Communications Act, 2003, c. 21, $\$ \S 1.2-1.3,1.6$ (Eng.).

57 Sean Poulter, Mobile Networks To Fight Price Cuts, DaILY Mall, Oct. 1, 2003, at 15, available at 2003 WL 64341354. 
the most significant regulatory body to date to impose mobile termination rates. We will therefore discuss Oftel's specific rationales for doing so in greater detail throughout this article.

\section{European Commission}

In 2002, mobile termination rates in Europe ranged from $0.23 €$ per minute for Mobistar in Belgium to $0.128 €$ per minute for Sonera in Finland. ${ }^{58}$ In response to complaints from the FCC and U.S. long-distance carriers that those termination rates were excessive, the European Commission, acting through its Directorate General for Information and Society ("DG InfoSoc"), adopted new guidelines in February 2002. ${ }^{59}$ The guidelines sought to articulate how Europe's NRAs should define market power and competition for the purpose of establishing a list of telecommunications services that require regulation. ${ }^{60}$ In February 2003, DG InfoSoc included call termination in the array of services that NRAs are required to regulate. ${ }^{61}$ DG InfoSoc gave member states until July 25 , 2003 to pass any regulations that it had promulgated, ${ }^{62}$ but only three of the fifteen member states met the deadline. NRAs in France and the Netherlands indicated that passage of such laws might be significantly delayed, ${ }^{63}$ and Germany had not implemented the provisions on mobile termination rates as of August $2003 .{ }^{64}$ In January 2004, the EU Commission's "Article 7 Task Force" strongly criticized, in published comments, the implementation of the EU Regulatory Framework by the Finnish Communications Regulatory Authority ("Ficora") with respect to its decision to exclude fixed-to-mobile termination rates from regulatory remedies. This development may have significant ramifications for regulation of mobile termination rates in the EU. ${ }^{65}$

58 Michelle Donegan \& Simon Dux, Rate Cuts Won't Stop Mobile Data, COMM. WEEK INT'L, Jan. 1, 2003, at 1, available at 2003 WL 13588339.

59 Commission Directive 2002/21/EC, Annex I, 2002 O.J. (L 108) 33; Guidelines on the Assessment of Significant Market Power in the Communications Industry, Global Couns. MAG., Sept. 1, 2002, at 55, available at 2002 WL 20572608.

60 Commission Directive, supra note 59, at 33.

61 Commission Recommendation 2003/311/EC, 2003 O.J. (L 114) 45.

62 Slow Road to Reform, Construction PLUS, Aug. 4, 2003, available at 2003 WL 59628364 .

63 Id.

64 Id. MTRs are not regulated in Germany.

65 For discussion and analysis, see Reinhard Schu, EU Commission Says that NRAs Must Set Aside National Laws Incompatible with the EU Regulatory Framework, ARNOLD \& PORTER EUROPEAN TELECOMS NEWSL., Jan. 2004, available at http://aporter.pair.com/newsletter/79911_1.pdf. 
4. Other National Regulatory Authorities and National Competition Authorities within the European Union

European MNOs also have faced investigations of their mobile termination rates by other national competition authorities and national regulatory authorities. In July 2003, the Irish telecommunications regulator, ComReg, ordered the two leading mobile companies, Vodafone and $\mathrm{mm} 02$ Ireland, to decrease their mobile termination rates. ${ }^{66}$ The Italian Ministry of Communications, which has regulated mobile termination rates since the 1990 s, also ordered MNOs to reduce mobile termination rates in February 2002. ${ }^{67}$ The competition authority in the Netherlands, $\mathrm{NMa}$, announced in July 2003 that it would investigate mobile termination rates after Opta, the telecommunications regulator, had held that Dutch MNOs enjoyed monopoly power over call termination on their customers' networks. ${ }^{68}$

\section{Japan}

Although mobile termination rates are lower in Japan than in either Australia or the European Union, the U.S. Trade Representative ("USTR") has nonetheless pressured the Japanese government to order MNOs to decrease mobile termination rates further. ${ }^{69}$ USTR reported that, at the urging of the Ministry of Public Management, Home Affairs, Posts, and Telecommunications ("MPHPT"), Japanese MNOs reduced mobile termination rates by $12.5 \%$ in 2001 and $5.5 \%$ in $2002 .{ }^{70}$ It bears emphasis

66 COMM'N FOR COMMUNICATIONS REGULATION, MOBILE ACCOUNTING SEPARATION AND COSTING METHODOLOGIES, INFORMATION NOTICE 03/71, at 5 (June 27, 2003), available at http://www.comreg.ie/_fileupload/publications/ComReg0371.pdf; Press Release, Commission for Communications Regulation, ComReg Welcomes Reductions in Mobile Termination Rates Ensuring that Irish Rates Stay Among the Lowest in Europe (July 28, 2003), available at http://www.comreg.ie/_fileupload/ publications/PR280703.pdf.

67 Ministro delle COMUNICAZIONI, CONDIZIONI ECONOMICHE DELle COMUNICAZIONI FISSO-MOBILE ORIGINATE DALLA RETE TELECOM ITALIA, DELIBERA NO 10/99, available at http://www.comunicazioni.it/it/index.php?IdPag=407; Preliminary 2002 Telecom Italia Mobile SpA Earnings Conference Call-Final, FIN. DISCLOSURE WIRE, Mar. 10, 2003, available at 2003 WL 6693282 .

68 Beleidsregels Inzake de Regulering van Mobiele Terminating Tarieven [Policy Rules Regarding the Regulation of Mobile Terminating Tariffs], OPTA/IBT/2002/2200802, I 22 (Mar. 28, 2002), available at http://www.opta.nl/download/mta_policyrules_300902.pdf; Joel Cooper, Competition Authority To Investigate Dutch Mobile Termination Charges, WMRC DAILY ANAL YSIS, July 2, 2003, available at 2003 WL 58435339.

69 U.S. TRADE REPRESENTATIVE, 2002 NATIONAL TRADE Estimate REPORT ON FOREIGN TRADE BARRIERS 205 (Apr. 2, 2003), available at http://www.ustr.gov/reports/nte/2002/japan.PDF; U.S. TRADE REPRESENTATIVE, RESULTS OF 2003 "SECTION 1377" REVIEW OF TElECOMMUNICATIONS AGREEMENTS 2 (Apr. 2003), available at http://www.ustr.gov/sectors/industry/Telecom1377/2003/2003-04-02-results.pdf [hereinafter USTR 2003 SECTION 1377 REVIEW].

70 USTR 2003 SECTION 1377 REVIEW, supra note 69, at 2; Jeffrey Silva, Long-Distance 
that the Japanese MNOs voluntarily made these reductions. No formal regulation exists by which the Japanese government mandates reductions in mobile termination rates, although the MPHPT actively monitors the mobile termination rates charged by MNOs. In August 2002, the MPHPT said that it would seek further reductions if it found that mobile termination rates were not reasonable. ${ }^{71}$

In November 2002, the Ministry granted some landline operators (as opposed to MNOs) the power to set retail prices for fixed-to-mobile calls, and it agreed to study the issue in more depth "to put in place rapidly an efficient and transparent system for setting reasonable charges for interconnection." ${ }^{72}$ In its 2002 annual report, NTT DoCoMo, Japan's largest MNO, warned that the MPHPT's decision to empower landline operators to set mobile termination rates could significantly reduce its quarterly earnings. ${ }^{73}$ NTT DoCoMo also expressed concern that fixed-line callers would use Internet protocol ("IP") telephony to contact a mobile customer, thereby reducing its revenues because NTT DoCoMo does not derive any revenue from such a call other than the interconnection fees. ${ }^{74}$ NTT DoCoMo's concern suggests that voice over Internet protocol ("VOIP") might soon constrain mobile termination rates. ${ }^{75}$

In October 2002, the FCC argued that high termination charges abroad were responsible for high telephone rates for international calls made from the United States. In January 2003, NTT DoCoMo responded to the FCC that the appearance of high rates for calls originating in the United States in fact reflected surcharges that long-distance carriers imposed on calls to Japanese mobile subscribers, rather than high mobile

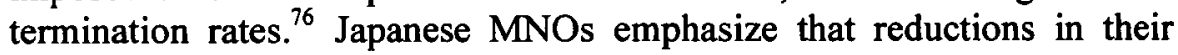
fixed-to-mobile termination rates are not always passed on in full to international callers. ${ }^{77}$

Carriers Question Japan's Wireless Interconnect Fees, RCR WIRELESS NEWS, May 27, 2002, at 4, available at 2002 WL 10370838.

71 Ministry of Pub. Mgmt., home Affairs, Posts, \& Telecomms., Telecomms. COUNCIL, FINAL REPORT ON DESIRABLE PRO-COMPETITIVE POLICIES IN THE TElECOMMUNICATIONS BUSINESS FIELD FOR PROMOTING THE IT REVOLUTION $\S 2-2$ (Aug. 7, 2002), available at http://www.soumu.go.jp/joho_tsusin/eng/Resources/Council/030312_1. html.

72 Ministry OF PUB. MGMT., Home AfFairs, Posts \& Telecomms., Telecomms. BUREAU, INT'L POLICY DIVISION, INT'L AFFAIRS DEP'T, DECISION CONCERNING APPLICATION BY Heisei DeNDEN CO., LTD. BASEd ON ARTICLE 39-3 OF THE TEleCOMM. Bus. LaW (Nov. 22, 2002), available at http://www.soumu.go.jp/joho_tsusin/eng/Releases/Telecommunications/ news021122_1.html.

73 NTT DOCOMO, 2003 ANNUAL REPORT 65 (English ed. 2003).

74 Id.

75 As we explain in greater detail later in the paper, firms that offer VOIP pay the off-net mobile-to-mobile termination charge rather than the fixed-to-mobile termination charge.

76 COMMENTS BY NTT Docomo InC., IN RE INTERnational SETtLements POlicy REFORM INTERNATIONAL SETTLEMENT RATES, IB Dkt. No. 02-324, at 3-5 (Jan. 14, 2003), available at http://gullfoss2.fcc.gov/prod/ecfs/retrieve.cgi?native_or_pdf-pdf\&id_document $=6513402563$.

77 Id.; Jeffrey Silva, U.K. Termination Issue Crosses Atlantic, RCR WIRELESS NEWs, Jan. 


\section{Summary of Regional Regulatory Initiatives}

In countries that use CPP, telecommunications regulators have initiated several efforts to regulate fixed-to-mobile termination rates. Table 1 summarizes the regional regulatory initiatives.

\section{Table 1: Summary of Regional Regulatory Initiatives Relating to Mobile Termination Rates, as of October 2003}

\begin{tabular}{ll}
\hline Country & Initiatives Relating to Mobile Termination Rate ("MTR") \\
\hline Australia & ACCC issued discussion paper, but has not issued final decision. \\
France & ART ordered MTR reduced to $0.1494 €$ per minute by January $1,2004$. \\
Germany & $\begin{array}{l}\text { RegTP does not regulate MTRs because it concluded that MTRs were suffi- } \\
\text { ciently low. }\end{array}$
\end{tabular}

Ireland ComReg reached an agreement with Vodafone and mm02-Ireland to decrease MTRs.

Italy $\quad$ AGCOM ordered MTR reductions to $0.1495 €$ per minute.

Japan MPHPT reduced rates by $14.2 \%$ in 2001 and $5.5 \%$ in 2002 ; MPHPT empowered some landline operators to set MTRs. At the same time, MPHPT initiated freedom of choice for relay carriers regarding fixed-to-mobile phones from 2005.

The Netherlands Opta reduced MTRs to best practice rates as determined by averaging MTRs charged by other European MNOs.

United Kingdom Oftel recommended 14\% to 15\% reductions on MTRs per year until 2006.

Sources: Press Release, Autorité de Régulation des Télécommunications, Fixed-to-Mobile Call Prices Lowered (Oct. 2003), available at http://www.art-telecom.ff/communiques/pressrelease/2003/ang0331.htm; Letter from Vodafone, to Ms. Gloria Blue, Executive Secretary, United States Trade Representative 4 (Jan. 23, 2004), available at http://216.239.39.104/search?q=cache:QFE_FDImvs0J:www.ustr.gov/sectors/industry/Telecom1377/2 $004 /$ reply.

For example, in the United Kingdom, Oftel has implemented mandatory reductions in mobile termination rates. Regulators in the Netherlands and Ireland have sought "voluntary" agreements to reduce fixed-to-mobile termination rates. MNOs have responded to these 
regulatory pressures by warning that other mobile rates will increase and deployment of $3 \mathrm{G}$ systems will be retarded. Such potential costs of price regulation will fall primarily on local consumers.

\section{The Federal Communications Commission and U.S. Trade Representative's Support for Regulation of Mobile Termination Rates Outside the United States}

In July 1999, the FCC studied the merits of CPP in the United States. $^{78}$ The Cellular Telecommunications Industry Association ("CTIA"), the industry trade association representing U.S. MNOs, favored supplementing MPP with CPP. ${ }^{79}$ CTIA argued that CPP, combined with the growing popularity of prepaid plans, would allow lower income groups to enjoy wireless calling. ${ }^{80}$ In conjunction with CPP, CTIA endorsed a notification system that would inform the fixed-line caller that he would be billed for the call. ${ }^{81}$ CTIA did not support notification that would identify the MNO connecting the call or the termination rate that the caller would be charged; CTIA argued that providing this information would be prohibitively expensive for the MNOs. ${ }^{82}$ Finally, CTIA urged the FCC to refrain from regulating mobile termination rates if it did allow CPP as an option. ${ }^{83}$ Interest in CPP as a possible supplement to MPP in the United States waned in 2000 as AT\&T Wireless and other MNOs introduced onerate, bucket plans. ${ }^{84}$ Because the mobile subscriber's marginal cost of mobile termination under a bucket plan is zero if the mobile customer's allotted minutes exceed the used minutes, the question of who should pay for a call that terminates on a U.S. mobile network became hypothetical. By 2002, analysts dismissed any possibility that CPP would supplement MPP in the United States. ${ }^{85}$

In September 2002, the FCC released a "consumer alert" warning U.S. consumers that "when wireline U.S. customers call foreign wireless customers, foreign carriers may pass through to the U.S. carrier the additional cost of connecting the wireless call. ${ }^{, 86} \mathrm{~A}$ month later, the FCC

78 Calling Party Pays Service Offering in the Commercial Mobile Radio Services, WT Dkt. No. 97-207, 14 F.C.C.R. 10,861 II (proposed July 9, 1999).

79 COMMENTS OF CTLA, CAllINg PARTY PAYS SERVICE OFFERING IN THE COMMERCIAL MOBILE RADIO SERVICES, WT Dkt. No. 97-207, IT 1-2 (Sept. 17, 1999), available at http://www.wow-com.com/filing/pdf/ctia091799.pdf.

$80 \quad I d .92$

$81 I d . \Uparrow 3$

$82 \quad I d$.

83 Id. $\mid 4$

84 See, e.g., Heather Forsgren Weaver, Sugrue: Wireless Bureau Spent Too Much Time on CPP, RCR WIRELESS NEWS, Feb. 3, 2003, at 11, available at 2003 WL 9785971.

85 Id.

86 Federal Communications Commission, Consumer Advisory, Surcharges for International Calls to Wireless Phones, Oct. 6, 2003, at http://ftp.fcc.gov/cgb/consumerfacts/surcharge.html. 
issued a notice of proposed rulemaking ("NPRM"), the final portion of which addressed "the issue of foreign mobile termination rates and whether such rates are detrimentally affecting U.S. consumers and competition in the U.S.-international services market." ${ }^{.87}$ Noting that mobile termination rates approached $\$ 0.33$ per minute in some countries, the NPRM asked, "How are foreign mobile carriers or landline carriers involved in mobile termination able to exert market power in this context, given that ... we have found that the international market has become substantially more competitive?",88

The USTR under both the Clinton and second Bush administrations has undertaken efforts to negotiate reductions in foreign mobile termination rates through bilateral agreements and the World Trade Organization ("WTO"). Since 1997, the United States has reached agreements regarding mobile termination rates with the European Union, Japan, Singapore, and Taiwan. ${ }^{89}$ In April 2003, the USTR expressed concern about Australian mobile termination rates to the Australian government, which directed the ACCC to seek public comment and further review. ${ }^{90}$

Each year, the USTR solicits comment on whether other countries are complying with market-opening commitments made pursuant to the WTO agreement on basic telecommunications services. This inquiry, conducted pursuant to Section 1377 of Title 19 of the U.S. Code, supplies the USTR with the factual record that it uses to write its annual report on alleged WTO violations by trading partners of the United States. ${ }^{91}$ In 2002, the three large American interexchange carriers-AT\&T, MCI WorldCom, and Sprint-complained to the USTR that they were being harmed by high fixed-to-mobile termination rates in other nations. In March 2002, the Competitive Telecommunications Association ("CompTel") complained to the USTR about high mobile termination rates in Italy. ${ }^{92}$ CompTel argued that, unlike its French and U.K. counterparts, the Italian NRA ("AGCOM") had failed to decrease mobile termination rates

87 International Settlements Policy Reform 17 F.C.C.R. 19,954 ๆ 51 (2002).

88 Id.

89 U.S. TRADE REPRESENTATIVE, FIRST REPORT TO THE LEADERS ON THE U.S.-JAPAN Regulatory Reform and COMPETITION POlicy InItiative, Fact SheEt 2 (June 25, 2002), available at http://www.ustr.gov/regions/japan/2002-06-25-report_to_leaders-factsheet.PDF ("Reaffirming that Japan's dominant mobile carrier, NTT DoCoMo, is required to offer cost-based, non-discriminatory interconnection rates to other operators.").

90 AUSTL. COMPETITION \& CONSUMER COMM'N, supra note 32, at 50; Simon Hayes, Canberra Rejects Move on High Wholesale Prices, THE AUSTRALIAN, Aug. 19, 2003, at 26, available at 2003 WL 61768705.

91 Omnibus Trade and Competitiveness Act of $1988 \S 1377$, 19 U.S.C. $\S 3106$ (1998).

92 Letter from CompTel, to Ms. Gloria Blue, Executive Secretary, United States Trade Representative (Mar. 13, 2002), available at http://www. comptel.org/filings/ustr_italy_sec1377_mar13_2002_add.doc. 
substantially. ${ }^{93}$ Although it acknowledged that in 1999 AGCOM had decreased mobile termination rates for the two largest MNOs (Telecom Italia Mobile and Omnitel Pronto Italia), CompTel argued that AGCOM had not taken any actions since then, despite opening an investigation into the matter in $2000 .^{94}$ Finally, CompTel complained that the Italian processes lacked transparency, noting that the data used by AGCOM to determine the mobile termination rate reductions had been known only to the two MNOs. ${ }^{95}$

The USTR accepted these complaints and made them part of its assessment of the state of foreign compliance with the WTO agreement. In its subsequent report issued in April 2002, the USTR cited evidence that MNOs in the EU and Japan charge termination rates for fixed-to-mobile calls that significantly exceed costs. ${ }^{96}$ The USTR estimated that, with the rapid growth in mobile wireless services, the burden of these above-cost charges on U.S. operators and consumers could soon reach billions of dollars annually. The USTR therefore urged Japan, the European Commission, and EU member states to ensure that MNOs charge what the USTR regarded as competitive mobile termination rates. ${ }^{97}$

The USTR's negotiations with Japan, first undertaken in 1997 under the Enhanced Initiative on Deregulation and Competition Policy and then in June 2002 under the U.S.-Japan Regulatory Reform and Competition Policy Initiative, led to an agreement to reduce Japan's mobile termination rates. ${ }^{98}$ Despite these reductions, the USTR continued to express concern over the subsequent implementation of the agreements. ${ }^{99}$ The USTR criticized NTT DoCoMo's termination rates in the 2002 Report on Trade Barriers. ${ }^{100}$ By May 2003, however, the USTR acknowledged that NTT

93 Id.

94 Id. at 1-2.

95 Id. at 2

96 U.S. TRADE REPRESENTATIVE, Results OF THE 2002 “SeCtion 1377" Review OF TELECOMMUNICATIONS TRADE AGREEMENTS 1 (Apr. 3, 2002), available at http://www.ustr.gov/sectors/industry/Telecom1377/2002review.PDF.

97 Id.

98 MINISTRY OF FOREIGN AFFAIRS OF JAPAN, THIRD JOINT STATUS REPORT ON THE U.S.JAPAN ENHANCED INITIATIVE ON DEREGULATION AND COMPETITION POLICY 1-2 (July 22, 2000), available at http://www.mofa.go.jp/region/n-america/us/report0007.html; U.S. TRADE REPRESENTATIVE, FIRST REPORT TO THE LEADERS ON THE U.S.-JAPAN REGULATORY REFORM AND COMPETTION POLICY INITIATIVE 3 (June 26, 2002), available at http://www.ustr.gov/regions/japan/2002-06-25-report_to_leaders.PDF.

99 U.S. TRADE REPRESENTATIVE, FOURTH JOINT STATUS REPORT UNDER THE U.S.-JAPAN ENHANCED INITIATIVE ON DEREGULATION AND COMPETITION POLICY, FACT SHEET 2 (June 30, 2001) (asserting that "to address these problems, Japan will[,] . . . in the case of mobile interconnection, ensure that tariffs for NTT DoCoMo are publicly disclosed and reflect the costs of an efficient operator").

100 U.S. TRADE REPRESENTATIVE, 2002 NATIONAL TRADE ESTIMATE REPORT ON FOREIGN TRADE BARRIERS 206 (Apr. 2, 2002), available at http://www.ustr.gov/reports/nte/2002/japan.PDF. 
DoCoMo had significantly reduced its mobile termination rates. ${ }^{101}$

As we noted earlier, Japanese MNOs told the USTR in January 2003 that U.S. long-distance carriers had not passed on Japanese reductions in fixed-to-mobile termination rates to their American customers. Vodafone similarly told the USTR in January 2003 that the majority of the cost to an American calling someone on an overseas mobile network comes from surcharges that U.S. long-distance operators impose. ${ }^{102}$ Vodafone noted that, despite a ten percent decline in the mobile termination rates in Europe since February 2001, AT\&T's retail surcharge to its long-distance customers did not decline. ${ }^{103}$

\section{Both Parties Pay for Mobile Calls in the United States}

The United States uses a MPP system for mobile termination rather than CPP. MPP forces mobile customers to internalize termination rates, which in theory should generate lower mobile termination rates. In addition, the intercarrier compensation regime in the United States has served to lower termination rates. Despite the theoretical predictions of the superiority of CPP in encouraging mobile penetration, mobile telephone subscribers in the United States actually use their mobile phones far more intensively than do subscribers in countries with CPP regimes, and mobile penetration in MPP countries is increasingly rapidly.

1. MPP and Reciprocal Compensation Agreements Obviate the Regulation of Mobile Termination Rates

Because the MPP system forces mobile subscribers to internalize termination rates, competition for mobile subscribers places downward pressure on mobile termination rates. The same competitive pressures do not exist in CPP regimes. In addition to using MPP, MNOs in the United States are entitled to a reciprocal compensation rate that provides for the recovery of "a reasonable approximation of the additional costs [to the carrier] of terminating" calls from the other carrier. ${ }^{104}$ In April 2001, the FCC issued the Unified Intercarrier Compensation NPRM, which sought comment on the application of its current orders and rules regarding

101 U.S. TRADE REPRESENTATIVE, SECOND REPORT TO THE LEADERS ON THE U.S.-JAPAN REGULATORY REFORM AND COMPETITION POLICY INITIATIVE 4 (May 23, 2003).

102 Letter from Vodafone Americas, Inc., to Gloria Blue, Executive Secretary, United States Trade Representative 3 (Jan. 24, 2003), available at http://www.ustr.gov/sectors/industry/Telecom 1377/2003/vodafone.PDF

103 COMMENTS OF VODAFONE ON NOTICE OF PROPOSED RULE MAKING, INTERNATIONAL SETTLEMENTS POLICY REFORM, IB Dkt. No. 02-234, 27 (Jan. 14, 2003), available at http://gullfoss2.fcc.gov/prod/ecfs/retrieve.cgi?native_or_pdf=pdf\&id_document=6513402557.

10447 U.S.C. § 252(d)(2)(A)(ii) (2004). 
asymmetric reciprocal compensation to fixed-to-mobile interconnection. ${ }^{105}$ In May 2001, the FCC's Wireless Telecommunications Bureau and Wireline Competition Bureau jointly declared that MNOs were entitled to the opportunity to demonstrate that their termination costs exceed those of incumbent local exchange carriers ("ILECs"). ${ }^{106}$ The Bureaus explained that the determination of "compensable wireless network components" should be based on whether the particular wireless network components are cost sensitive to increasing call traffic. ${ }^{107}$

In its Eighth Annual Report and Analysis of Competitive Market Conditions with Respect to Commercial Mobile Services, the FCC in 2003 credited its own rules on intercarrier compensation with keeping mobile termination rates low. ${ }^{108}$ The agency noted that, in contrast to the European average fixed-to-mobile termination rate of $\$ 0.16$ per minute in 2002 , the average mobile termination rate in the United States was $\$ 0.005$ per minute in 2002 (in addition to the airtime charge paid by the subscriber receiving the call), ${ }^{109}$ which roughly equaled the average rate for terminating traffic on fixed networks. ${ }^{110}$ The large difference between the European average and the American average suggests that the U.S. system of reciprocal compensation and MPP creates better incentives for MNOs to lower mobile termination rates than CPP does.

\section{Cellular Telephone Use Continues To Increase Significantly in} the United States and Canada

Some have argued that, under an MPP system, a mobile subscriber has an incentive not to give out his mobile phone number or to switch off his mobile phone when not placing calls so as to avoid being charged for incoming calls. ${ }^{11}$ But U.S. mobile operators have overcome these disincentives by introducing bucket plans, ${ }^{112}$ which permit the subscriber to purchase a certain level of minutes for a flat monthly charge. ${ }^{113}$ The

105 Developing a Unified Intercarrier Compensation Regime, Intercarrier Compensation for ISP-Bound Traffic, Implementation of the Local Competition Provisions in the Telecommunications Act of 1996 CC Dkt. No. 01-92, 16 F.C.C.R. 9610 ๆ 101 (2001).

106 Letter from Thomas J. Sugrue, Chief, Wireless Telecommunications Bureau, and Dorothy T. Attwood, Chief, Common Carrier Bureau, to Charles McKee, Senior Attomey, Sprint PCS, CC Dkt. No. 95-185, 16 F.C.C.R. 9597 (2001).

107 Id.

108 FCC Eighth Annual Report, supra note 19, \209.

109 Id. ๆ 207

110 Id.

111 See, e.g., Hausman, supra note 2, at 595.

112 FCC Eighth Annual Report, supra note 19, \213.

113 For example, Sprint PCS charges customers $\$ 45$ per month for a bucket of 500 "anytime" minutes. If the subscriber uses fewer than 500 minutes per month, he is charged $\$ 45$. If the subscriber uses more than 500 minutes per month, he is charged $\$ 45$ plus $\$ 0.40$ per minute for each minute in excess of 500 minutes. See Sprint, supra note 22. 
FCC in 2003 credited increases in the size of bucket plans, at declining rates, with being "a major driver of average mobile usage in the United States." The FCC noted that bucket plans may increase the accessibility of a mobile subscriber to his friends and family in an environment in which he pays for both incoming and outgoing calls. ${ }^{115}$ Indeed, at least one U.S. carrier, Nextel, began offering plans with free incoming minutes in 2003. ${ }^{116}$ Even without free minutes, the marginal cost of an incoming call is zero if the mobile customer is below the allotment of minutes in his bucket plan. The likelihood that a mobile customer will not exceed his allotment obviously increases as MNOs refine their bucket plans to allow the customer to supplement his monthly allotment with unused "rollover minutes" from the previous month. ${ }^{117}$

A comparison of mobile penetration rates and mobile telephone use across countries reveals the marginal effect of a particular mobile termination regime. Low minutes of use ("MOUs") in Europe and other CPP markets are partly attributable to the relatively large share of prepaid subscribers, who may not be able to afford to use more than their allocated number of minutes. High MOUs in the United States are attributable to the adoption of bucket plans and the associated low rates per minute. ${ }^{118}$ Table 2 summarizes these data.

114 FCC Eighth Annual Report, supra note 19, 1213.

115 Id.

116 Nextel, Nextel National Free Incoming Plans, at http://www.nextel.com/phones_plans/promos/promo_free_incoming.shtml (last visited Apr. 17, 2004).

117 The U.S. wireless carrier Cingular introduced a rollover plan in 2002, which credits customers for minutes not used in previous months. See Jesse Drucker, How To Dump Your Cellphone Company, WALL ST. J., Nov. 18, 2003, at D4.

118 Clearly, these large bucket plans do not reduce the marginal cost of a minute of use to zero, but the low prices available in the larger bucket plans have reduced the cost of accepting incoming calls substantially. In addition, the large number of free off-peak minutes available in many of these plans further reduces the cost of accepting calls in the U.S.'s MPP regime. 
Table 2: Penetration and Usage of Mobile

Telephony in Selected Countries

\begin{tabular}{lcccc}
\hline Country & $\begin{array}{c}\text { Penetration } \\
\text { (\% of } \\
\text { Population) }\end{array}$ & $\begin{array}{c}\text { Share of } \\
\text { Prepaid } \\
\text { (\% of Sub- } \\
\text { scribers) }\end{array}$ & $\begin{array}{c}\text { Minutes } \\
\text { of Use per } \\
\text { Subscriber } \\
\text { per Month }\end{array}$ & $\begin{array}{c}\text { Revenue } \\
\text { per } \\
\text { Minute } \\
(\$)\end{array}$ \\
\hline CPP & 68 & NA & 173 & 0.16 \\
Australia & 85 & NA & 146 & 0.24 \\
Finland & 63 & NA & 156 & 0.20 \\
France & 72 & 54 & 72 & 0.29 \\
Germany* & 93 & NA & 121 & 0.20 \\
Italy & 62 & 3 & 170 & 0.30 \\
Japan & 68 & 1 & 296 & 0.10 \\
South Korea & 85 & 69 & 132 & 0.22 \\
United Kingdom & $62-93$ & $1-69$ & $72-296$ & $0.10-0.30$ \\
Range & & & & \\
MPP & 37 & NA & 270 & 0.11 \\
Canada & 49 & 5 & 458 & 0.12 \\
United States & $37-49$ & 5 & $270-458$ & $0.11-0.12$ \\
Range & 59 & & \\
\hline
\end{tabular}

Source: FCC Eighth Annual Report, supra note 19, at D-14.

* MTRs are not regulated in Germany.

As Table 2 shows, average MOUs per subscriber per month are 270 in Canada and 458 in the United States, while MOUs per subscriber per month in the eight CPP countries in Table 2 range from 72 to 296 . On the other hand, CPP systems are associated with higher penetration rates, perhaps because they are used in countries with metered local calling charges on the fixed network that encourage mobile adoption. The penetration rate across the eight CPP countries in Table 2 ranges from sixty-two to ninety-three percent. However, the United States is reducing this gap, as Figure 2 shows. The growth rate in mobile penetration in the United States increased each year until 2002. 
Figure 2: Canadian and U.S. Mobile Penetration Rates, 1990-2002

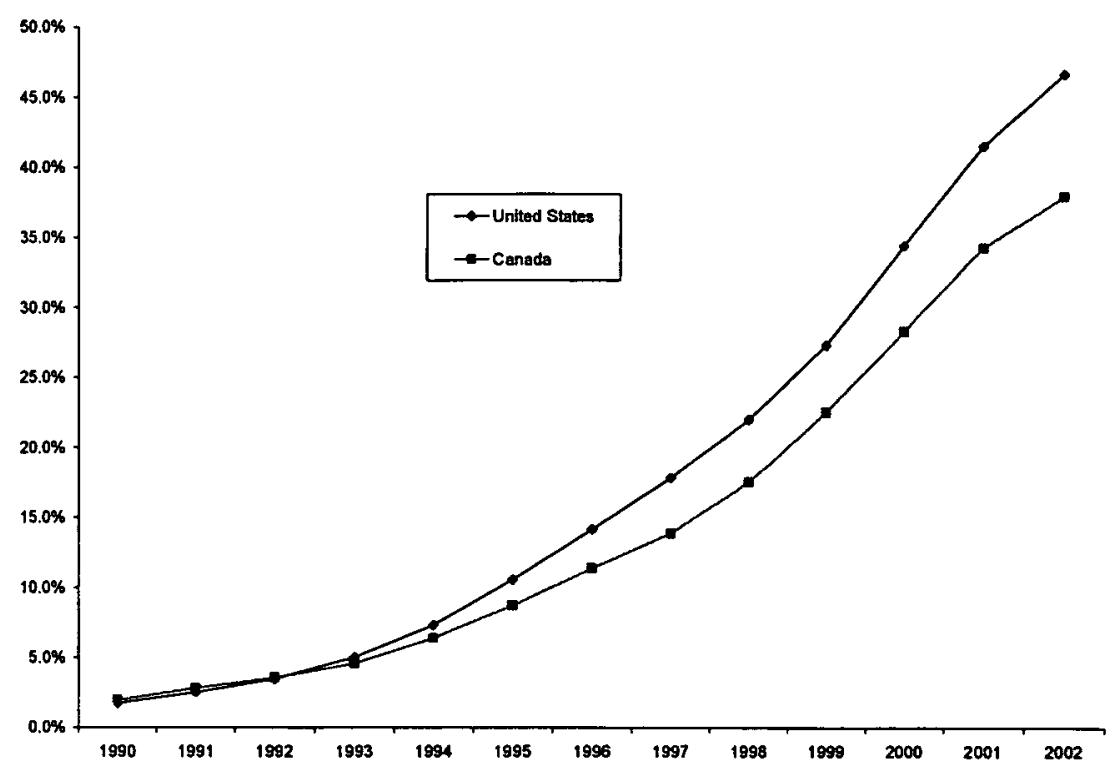

Source: FCC Eighth Annual Report, supra note 19, at app. D; CANADIAN WIRELEsS TeleComms. ASS'N, WIRELESS SUBSCRIBER STATISTICS, available at http://www.cwta.ca/industry_guide/SubscribersStats_Q2_03.pdf (last visited Apr. 26, 2004).

Indeed, if the growth rate continues to follow this S-shape pattern, mobile penetration in the United States should equal the penetration rates realized in most CPP countries between 2008 and $2014 .{ }^{119}$ The growth in mobile subscribers in Canada is similarly impressive-26.8 percent in $2000,22.3$ percent in 2001 , and 11.8 percent growth in $2002 .{ }^{120}$

The fact that mobile penetration in Canada and the United States will likely equal the penetration rates of CPP countries in the near term calls into question the conventional wisdom that CPP is the superior regulatory choice. The apparent primary advantage of CPP relative to MPP has been higher penetration rates; but, if that perceived advantage disappears, then how can CPP be considered superior to MPP? Mobile subscribers in MPP countries appear to use their mobile phones more intensively, presumably because of the pricing structure that MPP elicits from competitive MNOs.

119 By fitting a Gompertz S-curve to the data, we estimate that penetration will reach 85 percent by 2014 . By fitting a Pearl S-curve to the data, we estimate that penetration will reach 85 percent by 2008 . The Pearl model has a slightly higher R-squared than the Gompertz model (0.995 versus 0.992). For an explanation of these estimation techniques, see Peg Young \& J. Keith Ord, Model Selection and Estimation for Technological Growth Curves, 5 INT'L J. FoRECASTING 501 (1989).

120 Canadian Wireless Telecomms. Ass'N, Wireless Subscriber Statistics, available at http://www.cwta.ca/industry_guide/SubscribersStats_Q2_03.pdf (last visited Apr. 26, 2004). 
Moreover, the data suggest that MPP creates better incentives than CPP for MNOs to lower fixed-to-mobile termination rates. As Table 2 shows, the average revenue per minute in the United Kingdom is nearly twice the average revenue per minute in Canada and the United States $(\$ 0.220$ versus $\$ 0.115$ ). The higher prices in CPP countries (which are a weighted average of mobile-to-mobile, mobile-to-fixed, and fixed-to-mobile rates) may be attributable to the higher fixed-to-mobile termination rates. Because high minutes of use and low mobile termination rates contribute positively to the welfare of mobile subscribers, there is a strong case for policymakers to choose MPP over CPP. ${ }^{121}$

\section{Forces That Constrain an MNO's Market Power}

Market power exists in any industry characterized by imperfect competition. Hence, a demonstration of market power alone cannot justify regulatory intervention. It is the degree of market power that should interest regulators. In mobile telephony, multiple forces serve to constrain the market power of MNOs in the pricing of mobile termination. We now discuss those constraining forces and consider the extent to which MNOs have the ability to exploit market power.

\section{A. Demand Substitutes for Fixed-to-Mobile Calls}

The existence of substitutes constrains the market power of an MNO in the pricing of mobile termination. Demand substitutes for fixed-tomobile calls include mobile-to-mobile calls, mobile-to-fixed calls, data messages, and fixed-to-fixed calls.

\section{Mobile-to-Mobile Calls}

As mobile penetration increases, so does the percentage of people with a fixed phone who have access to a mobile telephone. This growing subscribership of wireless makes mobile-to-mobile calls an increasingly feasible substitute for fixed-to-mobile calls. Mobile-to-mobile calls on the same network (on-net) are not subject to a termination charge. As a result, an on-net call can often be less expensive than a fixed-to-mobile call, making the former an attractive substitute for the latter. The mobile carrier

121 Charles Jackson has suggested to us that economic welfare might improve if consumers were offered a choice of CPP or MPP. A similar choice already exists in most countries for the use of the land-line network. We agree that this added choice could create value for consumers, but implementing two different call-payment regimes might create confusion among wireless customers over who bears the cost of terminating each call. Carriers would have to develop software that notifies a caller whether the caller or the recipient pays the termination charges. 
loses the termination charge when the consumer switches from a fixed-tomobile call to an on-net mobile-to-mobile call, although the MNO gains the origination charge on the latter.

On the other hand, mobile-to-mobile calls from one network to another (off-net) are subject to a termination charge and are usually more expensive than fixed-to-mobile calls. Therefore, off-net mobile-to-mobile calls are not generally a good substitute for fixed-to-mobile calls. The MNO does not lose the termination charge when the consumer switches from a fixed-to-mobile call to an off-net mobile-to-mobile call.

Consequently, the constraining effect on mobile termination rates resulting from the ability of mobile-to-mobile calls to substitute for fixedto-mobile calls depends on the degree of mobile market penetration and the likelihood that the calling party and the called party are on the same mobile network. Although the constraining effect increases with the mobile penetration rate, it does not require, as Australian regulators incorrectly claimed, a "full penetration rate of mobile phones" for substitution to mobile-to-mobile calls to be an effective constraint on mobile termination rates. ${ }^{122}$ Substitution need only occur at a "critical share" of customers - that is, to a degree making a price increase unprofitable for the MNO. ${ }^{123}$ Depending upon the price-cost margins and the price elasticity of demand, the critical share of customers required to defeat, say, a five-percent price increase can be very small. Especially in industries in which a considerable proportion of costs are fixed-and therefore any revenue change directly affects the bottom line-iit will be necessary for only a small number of customers to switch to a substitute to render a price increase unprofitable.

Empirical evidence suggests that higher mobile penetration rates and lower mobile prices have already caused a significant subset of consumers to consider their mobile telephones to be their main phones and a substitute for fixed lines. ${ }^{124}$ A study conducted by the U.K. consultancy DotEcon in 2001 found significant evidence of call substitution between fixed and mobile telephony based on a telephone survey of more than 7,000 U.K. residents. ${ }^{25}$ Call substitution is defined as customers with access to both fixed and mobile phones choosing which mode to use on the

122 ACCC 2001 STUDY, supra note 18, at 44 (stating that "less than full penetration of mobile phones" might limit substitution possibilities).

123 For a more extensive discussion of critical share, see Jerry A. Hausman, Gregory Leonard \& Christopher Vellturo, Market Definition Under Price Discrimination, 64 ANTITRUST L.J. 367 (1996).

124 Oftel, however, regards the perception of a mobile as complementary to a fixed line as a factor reducing the substitution rate. See OFTEL STUDY, supra note 23, at 8.

125 DOTECON, FIXED-MOBILE SUBSTITUTION vii (Sept. 2001), available at http://www.dotecon.com/images/reports/fmsub3.pdf [hereinafter DOTECON FIXED-TO-MOBILE STUDY]. 
basis of the relative price of a call. Call substitution is distinct from accesslevel substitution, which involves customers choosing to make or retain subscriptions to fixed or mobile services depending on the relative prices of these services. These two substitutions are linked, as more call substitution will reduce the value of subscribing to a fixed line and thus lead to access-level substitution at the margin. ${ }^{126}$ Indeed, the ITU reported that mobile subscribers overtook fixed-line subscribers worldwide in 2002. ${ }^{127}$

DotEcon found that more than forty percent of those consumers with access to both fixed and mobile telephones at home use their mobiles to make calls from home at least sometimes, with the predominant reason being that mobile calls are cheaper than fixed calls. ${ }^{28}$ Mobile adoption would more often reduce fixed line usage than increase it; and, given hypothetical scenarios about the pricing of fixed and mobile services, respondents would switch both call and subscription decisions in response to relative price changes. ${ }^{129}$ Finally, DotEcon concluded from its comparative analysis of twenty OECD countries that an increase in mobile penetration has a significant negative impact on the growth of fixed-line penetration. ${ }^{130}$

One objection that Oftel raised against the hypothesis that on-net substitution constrains mobile termination rates is that any substitution to on-net calls could actually increase termination rates, as MNOs could meet the requirements of their more price-sensitive consumers through lower on-net call prices while raising termination rates for others. ${ }^{131}$ However, such an example of inverse-elasticity pricing is generally considered to increase efficiency. ${ }^{132}$ Oftel's objection thus rests only on distributional concerns, not on economic efficiency concerns.

\section{Mobile-to-Fixed Calls}

A second substitute for a fixed-to-mobile call is a reversal in the direction of the call. This substitution can be achieved by an informal

126 Id.

127 Robert Shaw, Int'l Telecomms. Union, Mobile Overtakes Fixed: What Happens Next?, Presentation to Seminar on Economic and Market Analysis for Central and Eastern European Countries and Baltic States, slides 10-13 (Sept. 9, 2003), available at http://www.itu.int/osg/spu/presentations/2003/prague-presentation-mobile-overtakes-fixed.pdf. Mobile penetration exceeds fixed-line penetration in several countries, including Cambodia, China, the Czech Republic, Morocco, Paraguay, Sweden, and Taiwan. Id. at 13.

128 DOTECON FIXED-TO-MOBILE STUDY, supra note 125, at 10, 59 figs.30-31.

129 Id. at 10,60 fig. 32 .

130 Id. at 30 . Using a regression analysis, DotEcon estimated the relationship between the rate of growth of fixed-line penetration and mobile penetration, controlling for other factors that might influence fixed-line penetration.

131 OFTEL STUDY, supra note 23, at 8.

132 We discuss Ramsey pricing in Part III. 
agreement between the calling parties whereby the calling party asks the receiving party to call back, or by a third-party vendor that automatically reverses the direction of the call. This alternative is contingent on the mobile party's consent, because the mobile party must pay the mobile origination charge under this alternative.

A reversal of the direction of the call results in the mobile network's losing the termination charge while gaining the origination charge. Mobile origination rates are likely to be lower than mobile termination rates, as competition between MNOs is likely to have a larger effect on origination rates than on termination rates. Consequently, the mobile network loses revenue on balance by receiving the origination charge instead of the termination charge.

Oftel and the ACCC have considered and rejected the theory that call reversal is an important substitute for fixed-to-mobile calls, but they have done so without any in-depth analysis. ${ }^{133}$ The degree to which call-back will constrain MNOs will depend on the calling party's awareness of the mobile termination rate and the degree to which mobile subscribers will consent to reversing the direction of the call.

By analogy, automatic call-back services became a significant constraint on high rates over particular international routes. ${ }^{134}$ The experience of the Hong Kong Telephone Company ("HKTC") is illuminating. Cable \& Wireless, the parent of HKTC, was willing to accept government compensation to surrender its "monopoly" over international outbound calls in Hong Kong earlier than provided for in the company's concession because call-back services had substantially eroded revenues. Hence, Cable \& Wireless came to value its exclusive franchise less than the net cash flows that the Hong Kong government apparently believed HKTC would earn on outbound calls. ${ }^{135}$

\section{Data Messages}

A data message (of up to 160 characters) can be sent from a computer or a mobile telephone to another mobile telephone. Data messages have the potential to substitute for fixed-to-mobile calls, because they also allow the caller to have immediate access to the receiver. To send a data

133 ACCC 2001 STUDY, supra note 18, at 18; OFTEL STUDY, supra note 23, at 8.

134 For a U.S. regulatory perspective on the competitive effect of international call-back, see VIA USA, Ltd., 9 F.C.C.R. 2288 I 3 (1994) (granting applications for authority to operate as international resale carriers), affd on reconsideration, 10 F.C.C.R. 9540 I 3 (1995). Additional information on call-back can be downloaded from FCC, International Bureau: Call-Back Services, at http://www.fcc.gov/ib/pd/pf/call-back.html (last visited Apr. 17, 2004).

135 For an elaboration of the Hong Kong experience with call-back services, see Paul W. MacAvoy \& J. Gregory Sidak, What is Wrong with American Telecommunications?, in COMPETrTION AND REGULATION IN TELECOMMUNICATIONS EXAMINING GERMANY AND AMERICA 69, 73-74 (J. Gregory Sidak, Christoph Engel \& Guenter Knieps eds., 2001). 
message, the caller needs to have access to a mobile telephone or to the Internet. Data messages are a good substitute for fixed-to-mobile calls to convey a specific piece of information, such as the time and place of a meeting. They can also be used to arrange call back by informing the called party of the request for a telephone conversation.

Data messages, however, are abbreviated. Moreover, they are not conveyed in real time. Despite these differences, data messages likely constrain fixed-to-mobile termination rates. As noted earlier, it is unnecessary for all customers to switch services in response to a price increase to constrain the price of termination rates. Consumers must substitute only to a degree that causes the price increase to be unprofitable for the MNO. Empirical evidence indicates that a significant share of mobile users reduce their reliance on voice calls in response to an increase in text messaging. ${ }^{136}$ This evidence supports the claim that such substitution indeed occurs.

Finally, firms that offer VOIP will pay the off-net mobile-to-mobile termination charge, not the fixed-to-mobile termination charge. ${ }^{137}$ Without having to subsidize handsets, VOIP offerings could cannibalize the existing fixed-to-mobile termination traffic and thus force the fixed-tomobile termination rate downward.

\section{Fixed-to-Fixed Calls}

Fixed-to-fixed calls do not allow the calling party to contact the mobile subscriber in real time when the mobile subscriber is not near a fixed-line connection. ${ }^{138}$ Nevertheless, fixed-to-fixed calls still could be a substitute for fixed-to-mobile calls. If the fixed-to-mobile call is not timesensitive, consumers will be willing to wait until the called party can be reached through a fixed connection. In that case, the mobile network loses the termination charge.

\section{Routing Fixed-to-Mobile Calls Through Mobile Networks}

In the United Kingdom, one or more firms began offering a service that would allow "GSM gateways" to route automatically a fixed-tomobile call through a domestic mobile network. To the MNO providing

136 DOTECON FIXED-TO-MOBILE STUDY, supra note 125, at 10, 68 fig.44.

137 See Tommaso Valletti, Obligations that Can Be Imposed on Operators with Significant Market Power under the New Regulatory Framework for Electronic Communications 14 (Sept. 2003) (unpublished manuscript, on file with the Yale Journal on Regulation), available at http://europa.eu.int/information_society/topics/ecomm/doc/useful_information/library/studies_ext_con sult/economic_expert_group/mobile\%20_valletti_final.pdf; text accompanying supra note 74.

138 A fixed-to-fixed call does allow the calling party to leave a message for the mobile subscriber, which can be returned from a fixed line or mobile line. 
termination, the call appeared to originate on-net. As a consequence, the terminating MNO would charge the caller the on-net mobile-to-mobile termination rate, which in the United Kingdom was lower than the fixedto-mobile termination rate. This particular service, however, did not last. In July 2003, the U.K. Radiocommunications Agency effectively shut down the service by ruling that it was unlawful for the firms offering the service to use spectrum allocated to mobile services in fixed applications. ${ }^{139}$

This anecdote shows that entrepreneurs can emerge to offer automatic arbitrage services to evade high fixed-to-mobile termination rates. Whether they do so is not a question of technology but rather a question of the size of the spread between the fixed-to-mobile termination rate and (in this case) the mobile-to-mobile termination rate. This actual experience blunts the force of Oftel's related criticism that automatic arbitrage services had not developed to facilitate mobile-to-fixed call-back.

\section{Other Services}

Other services that could be potential substitutes for fixed-to-mobile calls include e-mail, fax, paging, and voicemail. Paging can be used in much the same way as data messages to arrange call back. It does require the called party to own a pager. E-mail allows the calling party to send more complex messages to the called party than data messages permit. Although e-mail requires the calling party to access a computer-and the called party to have either computer access, or a mobile telephone or pager enabling him to receive e-mails-it is a substitute for a fixed-to-mobile call. Finally, fixed-line callers can leave extended voicemail messages on a mobile subscriber's fixed-line network. When the mobile subscriber checks those messages, he can return the call from his mobile phone or from his fixed-line connection.

\section{B. The Effect of Termination Rates on the Subscriber's Inbound Calls}

The preceding discussion demonstrates that fixed-line callers can substitute other forms of communication for calls to mobile subscribers in response to high mobile termination rates. Of course, fixed-line callers can also elect not to call mobile customers, or, at a minimum, can elect to decrease their demand for calling mobile customers. The elasticity of demand for fixed-to-mobile calls captures all substitution possibilities, including electing not to make contact. From the mobile operator's

139 For discussion and analysis, see Reinhard Schu, GSM Gateways and Other "Fixed Mobile" Terminals Partly Legalized in the UK, ARNOLD \& PORTER EUROPEAN TELECOMS NEWSL., July 18, 2003, available at http://aporter.pair.com/newsletter/gsm_gateways.pdf. 
perspective, the decision not to call a mobile subscriber is just as harmful as the decision to substitute to another form of communication. In particular, an MNO loses the entire margin of terminating a call onto its mobile network when a fixed-line caller decreases his demand to contact a mobile customer. Moreover, if mobile subscribers know that they will not receive calls from persons from whom they want to hear, the demand for mobile subscriptions will decline, which will further decrease the MNO's profits. Recognizing that potential loss, MNOs will moderate their pricing of mobile termination rates.

To evaluate the own-price elasticity of demand for fixed-to-mobile calls, one must distinguish between the market elasticity for fixed-tomobile calls and the elasticity of demand for calls to a particular network. The former describes the degree to which consumers will abstain from fixed-to-mobile calls entirely and switch to other means in response to an increase in the average market price for fixed-to-mobile calls. The latter describes the consumer reaction to an increase in the price of calling a particular mobile network. This latter demand elasticity is what an individual MNO will consider when setting its fixed-to-mobile termination rate and is likely to be substantially higher.

A study conducted by DotEcon for British Telecom ("BT") estimated that the long-run market demand elasticity for fixed-to-mobile calls was between -0.33 and -0.42 for daytime calls. Hence, the volume of fixed-tomobile calls would fall by about $0.4 \%$ for a $1 \%$ increase in the retail price. ${ }^{140}$ DotEcon found that market demand elasticities were higher for evening and weekend calls. The weighted average demand elasticity was estimated to be $-0.43 .{ }^{141}$ On the other hand, a U.S. study found the ownprice elasticity of demand for wireless calls to be -1.12 to -1.29 , which suggests that an MPP regime will discipline carrier termination charges in a competitive wireless market. ${ }^{142}$

When considering whether to raise the price of fixed-to-mobile termination rate by ten percent, a hypothetical monopolist of the mobile network would have to weigh the lost margins on four percent of its inbound calls from fixed networks (the marginal calls) against the increase in margins on ninety-six percent of its existing calls (the inframarginal calls). Because the elasticity of demand is higher for any individual

140 DotECON, Estimation OF FIXED to MOBILE PRICE ElASTICITIES 3 (2001), available at www.dotecon.com/images/reports/elastftm.pdf [hereinafter DOTECON ELASTICITY STUDY].

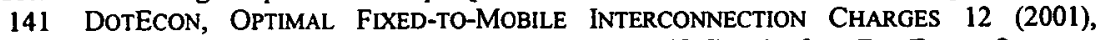
available at http://www.dotecon.com/images/reports/rmsyits.pdf [hereinafter DOTECON OPTIMAL ChARGES STUDY].

142 Allan T. Ingraham \& J. Gregory Sidak, Do States Tax Wireless Services Inefficiently? Evidence on the Price Elasticity of Demand (Mar. 2004) (unpublished manuscript, on file with the Yale $\quad$ Journal
http://www.criterionauctions.com/docs/IngrahamSidakWirelessTax06.pdf. 
competitive MNO, the incentive to raise the termination charge will be even less than that facing the hypothetical monopolist.

A hypothetical monopolist of the mobile network would expect to lose an even greater share of marginal customers in the mid-to-long term. The demand for any service is more price-inelastic in the short run. Thus, the price elasticity of demand for fixed-to-mobile calls should increase (in absolute terms) over time, further constraining the market power of MNOs vis-à-vis fixed-line callers. ${ }^{143}$ As we discussed above, text messaging and other innovative forms of communications will provide new substitution possibilities for fixed-to-mobile calls. Moreover, search costs and customer ignorance decline over time, further increasing the price elasticity of demand for fixed-to-mobile calls. As fixed-line consumers learn more about their calling options, they will become more pricesensitive. NRAs should not assume that there are no learning effects when deciding whether to regulate mobile termination rates.

\section{Closed User Groups: Mobile Customers' Concern for the Welfare of Their Callers}

An MNO can exercise market power only to the extent that its mobile subscribers are not sensitive to the price of incoming calls. If, to the contrary, enough customers choose their wireless carrier on the basis of incoming call charges, then the MNO will have an incentive to compete on mobile termination rates also. Although some evidence suggests that mobile subscribers are generally less concerned with the cost of incoming calls than with the price of outgoing calls, ${ }^{144}$ it is doubtful that consumers are ignorant about mobile termination rates and their dampening effects on incoming calls.

In general, the demand responses of calling parties in reaction to an increase in mobile termination rates will affect the mobile subscriber. If higher mobile termination rates reduce the incentives of other parties to call the mobile subscriber, the value of wireless access for the called party will decline. Consequently, higher mobile termination rates will increase the wireless subscribers' propensity to switch networks.

Research cited by Oftel indicates that thirteen percent of residential customers take into account incoming call charges when they buy their mobile packages. ${ }^{145}$ By contrast, thirty-one percent of small and medium enterprise business consumers consider the cheapest network to call when

143 Greater substitution possibilities increase the price elasticity of demand over time. See, e.g., GEORGE J. STIGLER, THE THEORY OF PRICE 32 (3d ed. 1978) ("A particular brand of coffee has a high cross-elasticity with respect to other brands-actually, on the order of +5 or +10 -even within a month or two.") (emphasis added).

144 OFTEL STUDY, supra note 23, at 5.

145 Id. 
choosing a network. ${ }^{146}$ However, Oftel's research also showed that, when choosing a network, both residential and business consumers tend to consider other factors-such as the price for outgoing calls, network coverage, and the choice of handset - to be more important than the price of incoming calls. ${ }^{147}$

A closed user group ("CUG") is generally defined as a group of subscribers who are as concerned about the price of receiving a call as the price of making a mobile call. ${ }^{148}$ Other definitions distinguish between a narrow CUG, in which the mobile owner is also the person who pays for the calls to its mobile, and a wide CUG, where a group of friends and family have an interest in keeping call costs down in general. ${ }^{149}$ An example of a narrow CUG is a family whose children call their parents' mobile phones, for which the parents pay the charges originating from both the fixed line and the mobile. Wider CUGs exist both in the private context, where a group of friends and family does not want to impose high costs on one another, and in the business context. In either case, the mobile subscriber's utility depends partly on the utility of his callers. The mobile subscriber has a substantial interest in minimizing rates paid by calling parties who are clients or potential sources of business. ${ }^{150}$ Furthermore, business mobile subscribers form a narrow CUG when employees of a firm call each other. In this case, the company will have to pay for both the calling party's and the called party's phone bill. ${ }^{151}$

The consequence of a CUG is that mobile subscribers will pay attention to the prices of incoming calls when choosing their mobile networks, thus placing competitive pressure on MNOs to keep termination rates low. Mobile subscribers in a CUG will also consider switching to a different $\mathrm{MNO}$ in response to an increase in the incoming call charges. The latter effect, however, would be constrained if mobile service contracts limit the subscriber's ability to switch networks immediately or if mobile termination rates of all other MNOs increased simultaneously. ${ }^{152}$

$146 I d$

147 Id.

148 ACCC 2001 STUDY, supra note 18 , at 17

149 OFTEL STUDY, supra note 23, at 6.

150 Several parties raised this argument in Calling Party Pays Service Offerings in the Commercial Mobile Services, WT Dkt. No. 97-207, 14 F.C.C.R. 10,861 (1999). See, e.g., COMMENTS of Bell atlantic in the Matter of Calling Party Pays Service Offerings IN THE COMMERCIAL MOBILE SERviCES, WT Dkt. No. 97-207, at 5 (Sept. 17, 1999), available at http://gullfoss2.fcc.gov/prod/ecfs/retrieve.cgi?native_or_pdf-pdf\&id_document=6009451163.

151 A related economic literature examines multi-sided platform markets, in which platform providers must account for the interactions among the demands of multiple groups of customers. See Jean-Charles Rochet \& Jean Tirole, Platform Competition in Two-Sided Markets, $1 \mathrm{~J}$. EUR. ECON. Ass'N 990 (2003). For an application of the theory to the credit card industry, see David S. Evans, The Antitrust Economics of Multi-Sided Platform Markets, 20 YALE. J. ON REG. 325 (2003).

152 Another argument raised against the constraining effect of CUGs on termination rates is that MNOs can differentiate these particular groups by charging them lower prices, whereas prices for 
Using a theoretical model of mobile telephony that assumes that all fixed costs are defrayed through fixed monthly charges, Mark Armstrong concludes that, when mobile customers do not internalize the welfare of their callers, regulation of mobile termination rates improves economic welfare:

[Total welfare] is maximized by setting [the termination charge] equal to [the marginal cost for terminating calls from the fixed sector], so that there should be marginal cost pricing of call termination under our assumptions. This in turn implies that [the fixed charge for mobile subscribers] equals [the fixed cost per mobile subscriber] in equilibrium, and there are no handset or other subsidies for mobile network connection at the optimum. Although mobile subscribers certainly benefit from high termination charges-since network connection is subsidized as a result-this benefit is more than outweighed by the costs this imposes on their callers. ${ }^{153}$

Armstrong shows that this result is true even in the face of call externalities - that is, when mobile subscribers gain utility from receiving a call. ${ }^{154}$ When one allows for mobile subscribers to care about their callers, however, competition among MNOs will result in termination rates roughly equal to marginal cost. ${ }^{155}$ Hence, when mobile customers fully internalize the welfare of their callers, Armstrong acknowledges that "the need for the control of mobile call termination in a competitive market is much reduced." 156 The relevant policy question, which we discuss in a later section, is whether regulatory intervention could improve the outcome regardless of the degree to which subscribers internalize the welfare of their callers.

\section{Supply Substitution}

Entering the mobile telephone business requires significant investment in network fixed assets. To terminate a call to a mobile subscriber, any operator needs access to the details of the subscriber's subscriber identity module ("SIM") card. This information is currently held only by that subscriber's MNO, so that any third-party termination service would require information sharing, an outcome that Oftel considered unlikely. ${ }^{157}$ Additionally, the development of other

other customers would remain unaffected or would even increase. See OFTEL STUDY, supra note 23, at 6-7.

153 Armstrong, supra note 13, at 341.

154 Id. at $341-42$.

155 Id. at 344.

156 Id.

157 OFTEL STUDY, supra note 23, at 11. 
technological solutions that achieve the same result-such as wireless local area networks or mobile virtual network operators-is uncertain. The low general likelihood of supply-substitution does not mean that potential supply-side effects have no constraining effect on mobile termination rates. We explain later why MNOs could have a strong incentive to differentiate themselves by offering service bundles to wireless subscribers that include low charges for incoming fixed-to-mobile calls.

\section{E. The Effect of Mobile Affiliation with a Fixed Network}

The economic theory of "double marginalization" explains why, in any given geographic market, an MNO affiliated with the fixed-network carrier will have a lower fixed-to-mobile termination rates than will unaffiliated MNOs. ${ }^{158}$ Double marginalization occurs when two companies have a vertical supplier-customer relationship. The upstream company sets its price, and thus its margin between price and marginal cost, to maximize its own profits. The downstream company likewise sets its price and margin to maximize its profit, treating what it pays the upstream company as a cost. If the upstream company begins to offer the downstream product also, it generally will set the final price of the downstream product to maximize its profits jointly from both the upstream and downstream products. The company offering the combined product will often find that it can increase its profits by lowering the price of the final product below the price that would be set in the previous situation. The company offering the combined product will take into account how a lower price on the final product will increase the sale of and profits from the upstream product, while a company offering only the final product will not.

In the United Kingdom, for example, by mid-1999 the mobile termination rates on calls from BT's fixed network to BT Cellnet's mobile network were slightly lower than those to Vodafone's mobile network and considerably lower than those to Orange's and One2One's mobile networks. ${ }^{159}$ One would not observe this result, however, in countries where the incumbent fixed-network operator is legally required to charge the same retail price for outgoing calls to all mobile networks, whether or not they are affiliates of the operator. In Denmark, for example, fixed and mobile operators negotiate interconnection agreements between their

158 See Joseph Spengler, Vertical Integration and Antitrust Policy, 58 J. POL. ECON. 347, 351-52 (1950). For a contemporary exposition, see DENNIS W. CARLTON \& JeFFreY M. PERLOFF, MODERN INDUSTRIAL ORganization 398-401 (3d ed. 2000); Jean TIROLE, The THEORY of INDUSTRIAL ORGANIZATION 174 (1988).

159 Working Party on Telecomm. \& Info. Servis. Policies, Org. for ECON. Cooperation \& Dev., Cellular Mobile Pricing Structures and Trends 50 (May 19, 2000), available at http://www.oecd.org/dataoecd/54/42/2538118.pdf [hereinafter MOBILE PRICING STRUCTURES]. 
networks, but TeleDenmark, the incumbent fixed-network operator that sets the retail price for fixed-to-mobile calls, is barred from differentiating prices for calls to mobile networks. ${ }^{160}$

\section{F. Summary of Forces That Constrain an MNO's Market Power}

Several forces constrain an MNO's market power in the provision of terminating access to mobile networks. Substitution possibilities for fixedto-mobile calls increase the elasticity of demand for fixed-line callers. By eliminating the double-marginalization problem, vertical integration of fixed-line operators into mobile services should lower fixed-to-mobile rates. Moreover, mobile customers partially internalize the welfare of their callers, which diminishes the economic justification for regulating mobile call termination.

III. If Market Failure Is Thought To Exist in Fixed-to-Mobile

Termination, Are Price Controls the Socially Optimal Remedy?

Should mobile rates, including termination rates, be set to equal marginal cost? We explain in this Part why such pricing would be unsustainable. In an industry that is characterized by high fixed costs, MNOs must charge prices that exceed marginal cost to make contributions to the recovery of overhead. This need to depart from marginal-cost pricing underlies the theory of Ramsey pricing. ${ }^{161}$ What, then, is the likelihood that regulators could set mobile termination rates that departed from marginal cost to the socially optimal degree? U.S. regulators similarly attempted-at great cost and with limited success-to determine the total element long-run incremental cost ("TELRIC") of fixed-line operators in the United States. That experience suggests that the search for the socially optimal mobile termination rate presents regulators with several insoluble empirical and practical problems.

\section{A. The Recovery of Large Fixed Network Costs and Customer Acquisition Costs Through Variable Charges}

Mobile telecommunications services require that MNOs incur significant fixed and common costs before the customer begins to make revenue contributions. For example, MNOs typically purchase licenses

160 Id. at 47.

161 See William J. Baumol \& David F. Bradford, Optimal Departures from Marginal Cost Pricing, 60 AM. ECON. REV. 265 (1970); Mark Boiteux, On the Management of Public Monopolies, 24 ECONOMETRICA 22 (1956); Frank P. Ramsey, A Contribution to the Theory of Taxation, 37 ECON. J. 47 (1927). For a nontechnical exposition of Ramsey pricing, see WILLIAM J. BAUMOL \& J. GREGORY SIDAK, TOWARD COMPETITION IN LOCAL TELEPHONY 35-40 (1994). 
from governments that convey the right to offer mobile service on designated frequencies. In a January 2001 auction for spectrum in the United States, MNOs paid nearly $\$ 5$ per MHzPop—or $\$ 1500$ per potential customer-for the typical $30 \mathrm{MHz}$ of bandwidth used for mobile networks. ${ }^{162}$ The price of spectrum in some European $3 \mathrm{G}$ spectrum auctions was even higher. ${ }^{163}$ Even though spectrum prices have declined from the $\$ 1500$ high-water mark, current spectrum values imply a cost of spectrum that is equal to $\$ 500$ per expected subscriber. ${ }^{164}$ A U.S. mobile carrier therefore must expect at least $\$ 500$ in the present discounted value of net cash flow over the life of the customer relationship simply to cover spectrum costs.

In addition to these upfront expenditures, MNOs incur significant subscriber acquisition costs ("SAC") through marketing expenses and handset subsidies. In accounting terms, the SAC is the cost of sale, which does not include advertising costs. The largest portion of an operator's SAC is the commission paid to the dealer and subsidies on handsets. ${ }^{165}$ Vodafone estimated that the average cost to connect a new customer in Japan in 2002 was $\$ 290{ }^{166}$ According to one U.S. analyst, from 2001 to 2002, wireless carriers' handset subsidies in the United States increased by eighteen percent, from $\$ 3.8$ billion to $\$ 4.5$ billion. ${ }^{167}$ As of 2003 , handset subsidies accounted for one-third of the $\$ 350$ that U.S. wireless carriers spend on average to sign up each new subscriber. ${ }^{168}$

In a perfectly competitive market, any firm is condemned to earn (no more than) zero economic profit in the long run, allowing it only to cover its current expenses, to pay interest to its creditors, and to provide a return to equity holders that is consistent with the prevailing level of interest payments so as to attract new capital. ${ }^{169}$ If the overall market for mobile services were effectively competitive (so that no excess profits were being earned), above-cost access prices for mobile termination would simply

162 The results of the auction can be downloaded from the FCC's web site at http://wireless.fcc.gov/auctions/35/charts/35market.xls (last visited Apr. 27, 2004) (MHzPOP connotes a megahertz of radio frequency provided to 1000 persons).

163 See, e.g., Paul Klemperer, How (Not) To Run an Auction: The European $3 G$ Auctions, 46 EUR. ECON. REV. 829, 830 (2002) (showing that $3 G$ spectrum prices per capita were $€ 615$ in Germany and $€ 650$ in the United Kingdom).

164 Assuming that (1) only 50 percent of potential customers will be converted into mobile subscribers, (2) the price of spectrum has decreased by two-thirds to $\$ 50$ per potential customer for 30 $\mathrm{MHz}$ of bandwidth, and (3) the mobile subscribers will be divided evenly across five carriers, the implied fixed cost per subscriber for $30 \mathrm{MHz}$ of spectrum is $\$ 500$ (equal to $\$ 50$ divided by 0.1 ).

165 It's Payback Time, Total Telecom, Apr. 2003, at 2.

166 Id.

167 Olga Kharif, So Long Fat Cell-Phone Subsidies?, BUS. WEEK ONLINE, Feb. 13, 2003, at 1, available at 2003 WL 6951835 (citing Martin Dunsby, vice-president at wireless consultancy InCode Telecom in La Jolla, California).

168 Id.

169 BAUMOL \& SIDAK, supra note 161 , at 30. 
offset the below-cost retail prices for other parts of the mobile services bundle - such as outgoing calls, mobile-to-mobile calls, or access charges. ${ }^{170}$ In this case, any (potential) excess profit made on termination by one mobile service would be competed away by other mobile services, effectively returning it to consumers.

An MNO could levy a large surcharge to recoup the average fixed cost when customers join its network. ${ }^{171}$ This pricing alternative, however, would reduce mobile penetration substantially and would be resisted by an MNO whose competitors are subsidizing handsets. In any event, it is not reasonable to believe that regulators (or consumers themselves) would tolerate an explicit surcharge for new mobile customers. The only viable pricing system, it appears, is to charge mobile usage rates that exceed marginal cost.

\section{B. The Role of Network Externalities in Mobile Telecommunications}

If the price for terminating a fixed-to-mobile call exceeds the cost of providing such termination, that fact alone would not mean that such pricing is inefficient. The existence of network externalities in mobile telecommunications could justify above-cost pricing. Network externalities in mobile services exist because a consumer's mobile subscription has a positive effect on other parties (both fixed and mobile subscribers). ${ }^{172}$ These parties benefit in various ways from the decision of a consumer to subscribe to mobile service. They benefit from any call they can place to the new subscriber. They also benefit from any call that the new subscriber places to them. Additionally, they benefit from the ability to contact, and to be contacted by, the new subscriber - the so-called "option value." This option value is in addition to the value that the parties place on the actual call as they exercise the option. Since callers to mobiles therefore benefit from the called party's decision to subscribe to a mobile network, the economically efficient charge they pay for the call must reflect this benefit. ${ }^{173}$ On the other hand, if the mobile subscriber were to face the full costs of the termination, he or she would be less likely to subscribe to the mobile service-even in situations in which such a subscription would enhance overall economic welfare due to the positive externalities obtained.

The difficult question is how to value the network externality. This

170 See ACCC 2001 STUDY, supra note 18; OFTEL STUDY, supra note 23, at 22.

171 This surcharge would be difficult to implement in practice because the average fixed spectrum cost declines with the number of subscribers enrolled.

172 Michael Katz \& Carl Shapiro, Network Externalities, Competition, and Compatibility, 75 AM. ECON. REV. 424 (1985); Michael Katz \& Carl Shapiro, Technology Adoption in the Presence of Network Externalities, 94 J. POL. ECON. 822, 823 (1986).

173 Oftel agrees with this assumption. OFTEL STUDY, supra note 23, at 37. 
valuation determines whether the difference between the price and the costs of fixed-to-mobile termination can be explained as a reflection of the network externality or instead as an exercise of market power by MNOs. Economists Jeffrey Rohlfs and James $M$. Griffin have suggested an approach that can be used to provide lower and upper bounds for the value of the network externality. ${ }^{174}$ They explain that the ratio of marginal social benefit to marginal private benefit - the Rohlfs-Griffin factor-is likely to lie in the range of one to two. Provided that the social benefits from additional joiners to the network are positive, the Rohlfs-Griffin factor cannot be below one. The upper bound of the Rohlfs-Griffin factor is two because it is unlikely that the existing members of the network will benefit by a greater amount than the potential new subscriber would..

Oftel's determination of the fixed-to-mobile termination rate was based on consultation from Rohlfs, whose early work at Bell Labs on network externalities resulted in the eventual publication of the seminal paper on the subject. ${ }^{175}$ In particular, Oftel assumed that the Rohlfs-Griffin factor is between 1.3 and $1.7 .{ }^{176}$ Because this new subscriber can be reached over the fixed network, Oftel reasoned, some of the benefits to existing network members of being able to contact a new subscriber have already been captured. ${ }^{177}$

In his theoretical model of optimal mobile termination rates, Armstrong allows for consumer surplus in the fixed-line sector to be an increasing linear function of the number of mobile subscribers. ${ }^{178} \mathrm{He}$ finds that the termination charge that maximizes total welfare under network externalities exceeds the marginal cost of termination:

[A] higher termination charge raises the equilibrium mobile subscriber utility via handset subsidies and the like, this in turn increases mobile subscription, which in turn raises the utility of fixed network subscribers because of the network externality effect. ${ }^{179}$

Armstrong concludes that the presence of network externalities provides a reason for pricing call termination above cost. Total welfare is greater when the prices of mobile handsets are subsidized by revenues from above-cost pricing for call termination, because an increase in the number of mobile subscribers enhances the value of the fixed network to all

174 See JefFrey RoHlfs, Economically EfFicient Bell-System Pricing 16 (Bell Lab. Discussion Paper No. 138, 1979); James M. Griffin, Welfare Implications of Externalities and Price Elasticities for Telecommunications Pricing, 64 REV. ECON. \& STAT. 59, 64 (1982).

175 Jeffrey Rohlfs, A Theory of Interdependent Demand for Communication Services, 5 BELL J. ECON. 16 (1974).

176 OFTEL STUDY, supra note 23, at 66-67.

177 Id.

178 Armstrong, supra note 13, at 342.

179 Id. at 343. 
subscribers. Nonetheless, Armstrong argues that the optimal mobile termination rate is still less than the unregulated rate. In particular, he argues that reducing the mobile termination charge below the unregulated rate would increase the welfare of callers to mobile subscribers more than it would decrease the welfare of mobile subscribers. ${ }^{180}$

Armstrong's model, however, does not allow for any requirement that variable charges defray some of the fixed costs of the MNO's operations. As we demonstrate in the following section, mobile termination rates that exceed marginal cost not only reflect network externalities, but also are consistent with the Ramsey pricing required to defray fixed costs.

\section{Termination Rates as Part of Ramsey (Quasi-Efficient) Pricing}

MNOs must use some source of revenue to defray the large fixed costs of building and operating mobile telecommunications networks, and of attracting new customers. It is unrealistic to assume that these fixed costs will be reflected in a customer charge for joining the network. Given the unavoidability of these large fixed and common costs, how should competitive MNOs set mobile termination rates?

Above-cost prices in the call termination segment of the mobile services bundle are consistent with constrained economic efficiency if they satisfy the Ramsey criterion. Ramsey pricing is a method of allocating common costs to the individual products of a multiproduct firm. ${ }^{181}$ Whereas economic welfare in a perfectly competitive market generally is maximized by setting the price of each product equal to its marginal cost, Ramsey pricing provides a solution to minimize welfare losses if marginalcost pricing yields revenues insufficient to cover the supplier's total costs. In particular, the damage to welfare is minimized if the shortfall is covered through smaller increases in the prices of goods whose demand is comparatively price-elastic and larger increases in the prices of goods whose demand is comparatively price-inelastic. Formally, Ramsey pricing requires that, where goods are neither substitutes nor complements, the percentage difference between the price of any good $X$ and the marginal cost of $X$ should be inversely proportional to the own-price elasticity of demand for $X$. When two goods are substitutes, the Ramsey pricing rule is stated in terms of superelasticities-that is, the optimal markup for good 1 is a function of both the elasticity of demand for good 1 and good 2-and the price of good 1 should be adjusted upward to account for the fact that such an increase raises the revenue received on good $2 .{ }^{182}$ When the goods

180 Id.

181 See supra note 161

182 See JEAN-JACQUES LAFFONT \& JEAN TIROLE, A THEORY OF INCENTIVES IN PRoCUREMENT AND REgulation 173 (1994); Jean-Jacques Laffont \& Jean Tirole, Creating 
are complements, as in call origination and call termination, the price of good 1 should be adjusted downward to account for the fact that such an increase decreases the revenue received on good $2 .{ }^{183}$

Evidence indicates that mobile subscribers are less sensitive to the price of call termination than the price of other parts of the mobile services bundle, such as outgoing calls. ${ }^{184}$ Consequently, efficiency-enhancing prices should be set so that common costs-which by definition are not attributable to any particular service within the mobile services bundleare included in the price of the less demand-elastic service, call termination. Mobile termination rates that exceed costs and yield excess margins therefore would enhance efficiency if they keep the prices of other services whose demand is very elastic closer to marginal costs.

Jerry Hausman demonstrates that the standard Ramsey solution to recovering common costs in a quasi-efficient manner requires that both mobile customers and their fixed-network callers pay variable charges that exceed marginal cost. ${ }^{185}$ After estimating the relevant demand elasticities, he finds that customers on the originating end of the call should pay a higher markup than the customers on the terminating end of the call. ${ }^{86} \mathrm{He}$ rejects the alternative of a two-part tariff because regulators would not likely require a fixed-line carrier to pay a fixed charge for the right to make calls to a mobile network. ${ }^{187}$

Oftel rejected the Ramsey pricing justification for seemingly high mobile termination rates because it found that the overall mobile services market in the United Kingdom was not competitive. MNOs had no incentive to set prices at a Ramsey-price level, Oftel said; rather, they had incentives to set prices above that level. ${ }^{188}$ Stated differently, Oftel argued that, free of regulation, mobile termination rates would exceed their Ramsey values because markets are not perfectly competitive. But, MNOs cannot be expected to choose mobile termination rates that perfectly accord with Ramsey pricing. Oftel is trying to regulate a highly competitive market that is not perfectly competitive.

In an empirical study of fixed-to-mobile termination rates in the United Kingdom, Drs. Christian Koboldt and Dan Maldoom of DotEcon found that the socially optimal Ramsey prices diverge significantly from the prices that would result from the application of Oftel's preferred "equi-

Competition through Interconnection: Theory and Practice, 10 J. REG. ECON. 227 (1996).

183 LAFFONT \& TIROLE, supra note 182, at 173.

184 See OFTEL STUDY, supra note 23, at 5 . This statement does not conflict with our earlier point that mobile subscribers are also sensitive to the price of incoming calls and therefore constrain the MNO's ability to raise mobile termination rates.

185 Hausman, supra note 2, at 596.

186 Id.

187 Id. $\$ 8.25$.

188 OFTEL STUDY, supra note 23, at 23, 81 . 
proportionate mark-ups" ("EPMU") ${ }^{189}$ Koboldt and Maldoom argue that competition among mobile operators must be assessed in terms of bundles of services, which include subscription revenues, revenues from mobileoriginated calls, and call termination revenues. Ramsey markups above long-run incremental cost ("LRIC") are derived by solving the following optimization problem: Choose a vector of prices that maximizes social welfare subject to the constraint that operating profits must exceed the fixed cost of building and maintaining the mobile network. Koboldt and Maldoom estimate demand elasticities for each of the three components of the bundle of services. ${ }^{190}$ Next, they obtain price, quantity, and cost estimates for each component from Oftel reports. Using these inputs, Koboldt and Maldoom estimate the following mean Ramsey markups for each component: $7.9 \%$ for subscription, $48.1 \%$ for mobile-originated calls, and $689.3 \%$ for fixed-to-mobile calls. ${ }^{191}$ They reject the hypothesis that the Ramsey markups on all three components are equal. ${ }^{192}$ They conclude that "whatever the shortcomings of the current structure of charges, a move toward setting charges for one particular service element-call termination-at the level of LRIC + EPMU has the potential of resulting in far worse outcomes." 193

\section{The Pitfalls of TELRIC-Style Regulation}

The Telecommunications Act of $1996^{194}$ requires the FCC to stimulate competition in local exchange services by creating a class of carriers, known as competitive local exchange carriers ("CLECs"), that are entitled to preferential access to incumbents' facilities at below-market rates. ${ }^{195}$ In this section, we review the associated cost of this policy, especially with respect to the misallocation of resources by the CLECs and the investment community.

189 DOTECON OPTIMAL CHARGES STUDY, supra note 141, at 21.

190 Id. at 11-17.

191 Id. at 21.

192 Id.

193 Id. at 24. For a similar critique of the FCC's recommendation for the use of equiproportional markups above LRIC for the pricing of unbundled network elements, see J. GREGORY Sidax \& Daniel F. SPulber, Deregulatory TaKings and the Regulatory Contract: The COMPETITIVE TRANSFORMATION OF NETWORK INDUSTRIES IN THE UNITED STATES 339-41 (1997).

19447 U.S.C. $\$ 251$ (c) (2004).

195 For an extended analysis of the economic effect of the unbundling provisions of the Telecommunications Act of 1996, see Robert W. Crandall, Local and Long Distance Competition: Replacing Regulation with Competition, in TeleCOMMUNICATIONS DEREGULATION AND FCC REFORM: FINISHING THE JOB (Jeffrey A. Eisenach \& Randolph J. May eds., 2000); Robert W. Crandall \& J. Gregory Sidak, Is Structural Separation of Incumbent Local Exchange Carriers Necessary for Competition?, 19 YALE J. ON REg. 335 (2002); Jerry A. Hausman \& J. Gregory Sidak, A Consumer Welfare Approach to the Mandatory Unbundling of Telecommunications Networks, 109 YALE L.J. 417, 452-53 (1999); J. Gregory Sidak, The Failure of Good Intentions: The WorldCom Fraud and the Collapse of American Telecommunications After Deregulation, 20 YALE J. ON REG. 207 (2003). 
The Telecommunications Act directed the FCC to identify network facilities of ILECs that should be made available to entrants at regulated wholesale rates. ${ }^{196}$ The FCC liberally interpreted this mandate by ruling that virtually every element of the ILECs' networks-from loops to switches to interoffice transport-should be made available at forwardlooking, long-run average incremental costs ("LRAIC") to competitors. ${ }^{197}$ Because this incremental-cost standard applied to each individual network element, the FCC's costing methodology was dubbed TELRIC, or total element long-run incremental cost. ${ }^{198}$ Moreover, the FCC determined that, because TELRIC rates are based on the most efficient network imaginable, TELRIC rates must be less than the actual historical costs of building and maintaining the ILECs' networks. Why should entrants, the FCC reasoned, be forced to pay higher access charges because of the ILECs' older networks that are now inefficient, given the changes in technology that have occurred since the ILECs built them?

TELRIC regulation was doomed to fail from the start. Solving for the socially optimal access rate in theory is different from asking state regulators to find the socially optimal access rate in practice. The latter requires precise estimates of the marginal cost of providing each network component required to deliver telephone service for a hypothetical mostefficient carrier. Empirical estimates of actual incremental costs cannot inform the solution and are difficult to obtain in practice. The search for the most efficient network leads to insoluble questions over, among other issues, the appropriate network design, the proper switching volumes, the necessity to maintain capacity to serve peak calling periods, and the type of switches used. Finally, the socially optimal access rate requires estimates of a markup factor above marginal cost that allows the incumbent carrier to contribute to fixed and common costs. Under a highly politicized environment, regulators are expected to estimate these variables with precision.

TELRIC rates vary enormously across states in areas of similar density. Table 3 shows the average TELRIC rate for U.S. states with available pricing data alongside the demographic and economic characteristics of those states.

19647 U.S.C. $\$ 251$ (c)(3) (2004) ("An incumbent local exchange carrier shall provide such unbundled network elements in a manner that allows requesting carriers to combine such elements in order to provide such telecommunications service.").

197 Review of the Commission's Rules Regarding the Pricing of Unbundled Network Elements and the Resale of Service by Incumbent Local Exchange Carriers, WC Dkt. No. 03-173, 18 F.C.C.R. 18,945 ๆ $18(2003)$.

198 Implementation of the Local Competition Provisions of the Telecommunications Act of 1996, First Report and Order, CC Dkt. Nos. 96-98, 95-185, 11 F.C.C.R. 15,499 ๆ 672-73 (1996). 
Table 3: Demographic and Economic Characteristics and Weighted Average "Loop" or "Access Loop" Rate in Selected U.S. States

\begin{tabular}{|c|c|c|c|c|c|}
\hline State & $\begin{array}{c}\text { Population } \\
(1,000 \mathrm{~s})\end{array}$ & $\begin{array}{c}\text { Population } \\
\text { Density } \\
\text { (people/sq } \\
\text { mile) }\end{array}$ & $\begin{array}{c}\text { Degree of } \\
\text { Urbanization }\end{array}$ & $\begin{array}{l}\text { Wage Rate } \\
\text { Index }\end{array}$ & $\begin{array}{l}1999 \text { Weighted } \\
\text { Average } \\
\text { Access "Loop" } \\
\text { Rate* (\$) }\end{array}$ \\
\hline $\mathrm{AL}$ & 4,370 & 86.1 & 70.1 & 93.9 & 19.04 \\
\hline $\mathrm{AZ}$ & 4,778 & 42.0 & 87.8 & 95.2 & 21.98 \\
\hline $\mathrm{CT}$ & 3,282 & 677.4 & 95.6 & 112.5 & 12.49 \\
\hline DC & 519 & $8,452.8$ & 100.0 & 133.3 & 10.81 \\
\hline $\mathrm{DE}$ & 754 & 385.4 & 81.6 & 117.0 & 12.05 \\
\hline GA & 7,788 & 134.5 & 68.9 & 91.2 & 16.51 \\
\hline IA & 2,869 & 51.4 & 44.6 & 101.4 & 8.20 \\
\hline ID & 1,252 & 15.1 & 38.3 & 93.6 & 25.52 \\
\hline IL & 12,128 & 218.2 & 84.5 & 100.4 & 9.81 \\
\hline $\mathbb{N}$ & 5,943 & 165.7 & 71.7 & 104.6 & 8.20 \\
\hline $\mathrm{KS}$ & 2,654 & 32.4 & 56.4 & 98.6 & 14.04 \\
\hline $\mathrm{KY}$ & 3,961 & 99.7 & 48.3 & 99.3 & 20.00 \\
\hline MA & 6,175 & 787.9 & 96.1 & 107.7 & 14.98 \\
\hline $\mathrm{MD}$ & 5,172 & 529.1 & 92.7 & 105.2 & 14.50 \\
\hline $\mathrm{ME}$ & 1,253 & 40.6 & 35.8 & 96.7 & 17.53 \\
\hline MI & 9,864 & 173.6 & 82.6 & 126.0 & 10.15 \\
\hline $\mathrm{MN}$ & 4,776 & 60.0 & 70.1 & 109.3 & 17.87 \\
\hline MT & 883 & 6.1 & 33.4 & 94.5 & 27.41 \\
\hline $\mathrm{NC}$ & 7,651 & 157.0 & 67.1 & 92.1 & 16.71 \\
\hline $\mathrm{NE}$ & 1,666 & 21.7 & 51.8 & 89.4 & 14.32 \\
\hline $\mathrm{NH}$ & 1,201 & 133.9 & 60.2 & 96.9 & 17.99 \\
\hline NJ & 8,143 & $1,097.6$ & 100.0 & 109.1 & 16.17 \\
\hline NV & 1,809 & 16.5 & 86.1 & 97.5 & 19.83 \\
\hline NY & 18,197 & 385.3 & 91.9 & 101.3 & 14.81 \\
\hline $\mathrm{OK}$ & 3,358 & 48.9 & 60.5 & 96.7 & 14.84 \\
\hline OR & 3,316 & 34.5 & 72.7 & 106.1 & 15.00 \\
\hline PA & 11,994 & 267.6 & 84.5 & 103.6 & 14.06 \\
\hline $\mathrm{TN}$ & 5,484 & 133.0 & 67.8 & 90.2 & 18.00 \\
\hline $\mathrm{TX}$ & 20,044 & 76.5 & 84.5 & 92.9 & 14.15 \\
\hline UT & 2,130 & 25.9 & 76.7 & 91.2 & 20.00 \\
\hline VA & 6,873 & 173.6 & 78.1 & 98.8 & 13.60 \\
\hline VT & 594 & 64.2 & 27.9 & 101.0 & 14.41 \\
\hline WA & 5,756 & 86.5 & 82.9 & 109.4 & 11.33 \\
\hline WI & 5,250 & 96.7 & 67.8 & 105.9 & 10.90 \\
\hline WV & 1,807 & 75.0 & 41.9 & 102.9 & 24.58 \\
\hline
\end{tabular}




\begin{abstract}
AVERAGE
5,248

424.4

70.3

101.9

15.77

Sources: Average access rate from Billy Jack Gregg, A Survey of Unbundled Network Element Prices in the United States (Spring 2001) (unpublished manuscript, on file with the Yale Journal on Regulation), available at http://www.sbc.com/Long_Distance/CA271/Vandeloop_Attach_A.pdf; U.S. population, pop. density, and degree of urbanization data from U.S. Census Bureau; Wage Rate Index from U.S. Department of Labor, Bureau of Labor Statistics (Sept. 2000).

* Equal to the weighted average UNE rate across all density zones in a given state, where the weights are equal to the share of the number of lines per density zone.
\end{abstract}

As Table 3 shows, certain states with very similar densities (Alabama and Washington each have roughly eighty-six persons per square mile) can have very different TELRIC rates $(\$ 19.04$ versus $\$ 11.33$ per month, respectively). The large discrepancy in rates may reflect political factors that are not captured in the demographic or economic data or simply large errors in trying to estimate network costs.

The search for the socially optimal mobile termination rate is similarly futile. It would begin by estimating the marginal cost of terminating a fixed network call onto a mobile network. Unfortunately, MNOs do not and probably cannot compute the precise marginal cost of an incoming call, and such an estimate would vary across networks and over time. Next, it would require an estimate of a markup to account for network externalities. As Armstrong demonstrates, the network externality effect depends on measures of (1) the change in the number of mobile subscribers with respect to a change in the net surplus offered by mobile networks, (2) the change in the net surplus offered by mobile networks with respect to a change in the mobile termination rate, (3) the utility of callers to mobiles, and (4) the change in the number of fixed-to-mobile calls with respect to a change in the price of the mobile termination rate. ${ }^{199}$ It is unreasonable to expect that regulators could measure these inputs with precision and then implement Armstrong's complex formula in an unbiased manner. As with the TELRIC process in the United States, regulators would be unable to determine the appropriate incremental cost with any precision. Even worse, regulators might attempt to skew the rate toward their favored constituency. ${ }^{200}$ Of course, to the extent that mobile customers care about the welfare of their callers, the unregulated rate will be competed down to the socially optimal rate, and the entire exercise would be a waste of social resources.

199 Armstrong, supra note 13, at 342.

200 Indeed, Sidak and Spulber argue that the FCC's UNE pricing reflects reverse Ramsey pricing for political expediency. See SIDAK \& SPULBER, supra note 193, at 369-70. 


\section{E. Summary}

Mobile termination rates cannot be equal to marginal cost because such an equality would prevent an MNO from recovering the high fixed costs of building and maintaining its network. In addition to the nature of costs, the demand for mobile telecommunications exhibits network externalities, which also imply that mobile termination rates properly exceed marginal cost. This need to depart from marginal-cost pricing of mobile termination exemplifies the theory of Ramsey pricing. In addition to these theoretical considerations, the practical difficulties with TELRIC price regulation of unbundled network elements since 1996 suggests how hard it would be for regulators to set mobile termination rates that would be socially optimal.

\section{The Lower Social Cost of Market-Based Solutions}

Economists typically scrutinize public policies according to the Pareto criterion - a proposed policy should be rejected if another policy exists such that welfare for every consumer under the alternative is greater than under the proposed policy. ${ }^{201}$ Put differently, a Pareto-superior public policy will make at least one person better off without making anyone else worse off. Because of theoretical and practical problems that plague costbased price regulation, we suggest several solutions to the problem of high fixed-to-mobile termination rates that do not involve price regulation.

A number of market-based solutions impose lower social costs by increasing competitive pressures on the MNOs from both calling parties and from the MNOs' own mobile subscribers. Regulators could encourage demand substitution by providing callers on fixed networks with more information about the particular network they call and the relevant termination rate. Providing mobile network subscribers with information about the prices of incoming calls would enable them to consider those prices when making calling choices. Shortening the contracts for mobile subscribers would facilitate switching networks in response to increases of termination rates.

\section{A. Mandatory Disclosure of Termination Rates to Customers of Fixed Networks}

The consumer reaction to an increase in the price of calling a particular network depends on whether calling parties recognize the identity of the mobile network that they are calling and the associated 
price. If consumers have this information, their choices would reveal the own-price elasticity of demand for fixed-to-mobile calls. On the other hand, if calling parties lack that particular information, they will base their decisions on their information about the market average price for making fixed-to-mobile calls-that is, the average price across all MNOs in the relevant market. The elasticity of demand faced by any particular firm is greater (in absolute terms) than the elasticity of demand for the entire market. Knowledge of an MNO's fixed-to-mobile termination rates would increase further the demand elasticity (in absolute terms) for calls to that network above the market elasticity. If termination rates are averaged, any increase in termination rates by one MNO would increase the average price by only a small share of the particular price increase. In addition, any overall decline in incoming call volume would affect all MNOs and not merely the MNO that had raised its price, thus spreading the demanddampening effect across all networks. For this reason, consumer termination rates should reflect the individual MNO's termination charges.

A simple way for the fixed-network operator to inform its customers of fixed-to-mobile termination rates is to list the set of relevant prices on its customers' monthly telephone bills. ${ }^{202}$ Suppose that ninety percent of domestic fixed-to-mobile calls by customers of a fixed-network operator were terminated onto four mobile networks. The fixed-network operator easily could provide the fixed-to-mobile termination rates for each of the four mobile networks on its customers' bills. Once he knows these prices, a customer of the fixed network could make an informed decision on whether to call subscribers of each of the four MNOs. If fixed-network operators are not providing information on these fixed-to-mobile termination rates to their customers, regulators may have to mandate such disclosure.

\section{B. Imposition of Dedicated Number Prefixes for Mobile Operators}

One obvious way for the fixed-line subscriber to identify the MNO terminating his call is to use dedicated number prefixes. For example, U.S. regulators require adult phone services to use designated prefixes so that customers will anticipate the charges. Mobile-to-mobile number portability, however, undermines this solution by severing the link between the identity of the MNO and the prefix. ${ }^{203}$ If ordered by

202 For example, SBC Communications lists foreign mobile termination rates on its website. SBC Communications, International Mobile Termination Charge, at http://www02.sbc.com/Products_Services/Residential/1,70-1-1-0,00.html (last visited Apr. 1, 2004).

203 The FCC ordered mobile-to-mobile number portability in February 2002 but granted the MNOs over one year to implement the rules. See In re Telephone Number Portability, Memorandum Opinion and Order on Reconsideration and Order on Application for Review, CC Dkt. No. 95-116, 17 F.C.C.R. 2,578 \1 (2002). 
regulators, fixed-to-mobile number portability would exacerbate this destruction of the identifying characteristic of numbering blocks. Hence, although number portability serves to constrain market power that any MNO has vis-à-vis its own customer, this policy has the unintended consequence of eliminating an easy potential solution to high mobile termination rates.

\section{Mandatory Disclosure of Termination Rates to Mobile Customers Upon Activation of Account}

One reason why mobile subscribers in CPP countries currently do not choose mobile networks based on the price of incoming fixed-to-mobile calls is that they lack information about the prices of such calls when they activate their mobile accounts. Even after activation of a mobile account, an MNO does not provide the fixed-to-mobile termination rate on the mobile customer's bill in CPP countries. Instead, those prices are presented to the fixed-network operator and passed on to its subscribers. ${ }^{204}$ It would require very little for each MNO to print its fixed-to-mobile termination rate on its monthly invoice to each of its mobile subscribers. More to the point, it would require very little for a fixed-line operator to print on its monthly invoices the fixed-to-mobile termination rates charged by the four or five MNOs that terminate the largest volume of traffic going from that fixed-line operator to CPP countries.

As fixed-to-mobile callers become informed of the prices for mobile termination through mandatory disclosure of termination rates, they will express their preferences to their intended call recipients, who in turn will express their preferences to MNOs. No one wants to subscribe to a mobile network that is prohibitively costly to call from a fixed network. The effect of this communication between the two user groups is for mobile subscribers to internalize more fully the welfare of their fixed-network callers, which, as we have argued, obviates regulation entirely.

\section{Elimination of Regulation of Mobile-to-Fixed Termination Rates}

Another deregulatory solution to the problem of high fixed-to-mobile termination rates is to allow the fixed-line network operator to negotiate its termination rates with the MNOs. As Julian Wright explains, "As long as the firms' bargaining power is roughly balanced, the tendency for cellular firms to set high termination charges may be alleviated. $" 205$

The economic theory of bilateral bargaining over access prices

204 MOBILE PRICING STRUCTURES, supra note 159, at 46.

205 Wright, supra note 5, at 313-14. 
confirms this view. In their seminal analysis of access pricing for rival networks, Professors Jean-Jacques Laffont of the University of Toulouse and Jean Tirole of the Institut d'Economie Industrielle have developed a model of two-way access pricing for telecommunications networks. ${ }^{206}$ Consumers first determine which of two networks to join, and, conditional on that choice, they choose their variable telephone consumption. To simplify their analysis, Laffont and Tirole assume that each network charges a per-minute access rate (reciprocal access pricing), and the fraction of calls originating on the first network that terminates on the second network is proportional to the second network's market share. ${ }^{207}$

Laffont and Tirole argue that high termination charges create a strong incentive for operators to increase their market shares to reduce their average marginal cost of producing calls, which is a weighted average of the marginal cost of completing a call on-net and off-net. In addition, they explain that higher access charges induce networks to raise their retail prices, which implies that the access charge might be an instrument for tacit collusion. ${ }^{208}$ In the presence of any one of four conditions, however, access charges will not provide a mechanism for facilitating collusion: (1) an imbalance in market shares, which creates a temptation for the highmarket-share network to charge low prices to avoid paying high access rates; (2) nonlinear pricing, which allows networks to use a monthly subscriber charge to build market share without inflating their off-net calls; (3) roaming charges, which also allow the networks to build market share without incurring access deficits; and (4) call-receiver subsidies, which allow the call receiver to internalize the benefits to the network of terminating the call. ${ }^{209}$

In addition, if the share of outgoing to incoming calls varies significantly across subscribers, carriers will attempt to attract customers who receive a large number of calls, thereby diminishing the appeal of high terminating access charges to the other carrier. This form of arbitrage defeated attempts by U.S. fixed-line carriers to negotiate high reciprocal access charges because it allowed the new competitive fixed-line entrants to target Internet service providers ("ISPs"), who have an extreme imbalance of incoming calls, as subscribers.

If any of these four conditions listed by Laffont and Tirole is satisfied, competition among networks forces access charges towards marginal cost. Moreover, in the presence of joint and common costs, the socially optimal

206 JEAN-JACQues LafFont \& JeAN TIROLE, COMPETITION IN TElecommunications 189

207 Id.

208 Id. at 195.

209 Id. at $196-207$ 
access rate might exceed the marginal cost of terminating a call. ${ }^{210}$ Since joint and common costs are significant in mobile networks, and nonlinear pricing is standard in the wireless industry, economic theory suggests that when networks are free to negotiate access prices, the resulting mobile termination rate will not deviate significantly from the socially optimal access price.

Finally, empirical evidence in the United States implies that voluntary negotiation among network operators leads to low termination rates. In the United States, MNOs may freely negotiate reciprocal termination rates with fixed-network operators and with other MNOs. As a result, fixed-tomobile termination rates roughly equal mobile-to-mobile termination rates. $^{211}$ In contrast, European fixed-network operators must accept incoming mobile calls at a regulated (and very low) rate. Table 4 shows the large disparity between mobile-to-fixed termination rates and fixed-tomobile termination rates as of 2000 for the thirteen developed countries in our sample. 
Table 4: Fixed-to-Mobile Termination Rates and Mobile-to-Fixed Termination Rates by Country, 1999-2000 (\$/Minute)

\begin{tabular}{|c|c|c|c|c|c|c|}
\hline \multirow[b]{3}{*}{ Country } & \multicolumn{3}{|c|}{1999} & \multicolumn{3}{|c|}{2000} \\
\hline & $\begin{array}{c}\text { Fixed-to- } \\
\text { Mobile } \\
\text { Termination }\end{array}$ & $\begin{array}{l}\text { Mobile-to- } \\
\text { Fixed } \\
\text { Termination }\end{array}$ & & $\begin{array}{c}\text { Fixed-to- } \\
\text { Mobile } \\
\text { Termination }\end{array}$ & $\begin{array}{l}\text { Mobile-to- } \\
\text { Fixed } \\
\text { Termination }\end{array}$ & \\
\hline & $\begin{array}{l}\text { Rate } \\
\text { (A) }\end{array}$ & $\begin{array}{c}\text { Rate } \\
\text { (B) }\end{array}$ & $\begin{array}{c}\text { Ratio } \\
(\mathrm{A}) /(\mathrm{B})\end{array}$ & $\begin{array}{c}\text { Termination } \\
\text { Rate } \\
\text { (A) }\end{array}$ & $\begin{array}{c}\text { Termination } \\
\text { Rate } \\
\text { (B) }\end{array}$ & $\begin{array}{c}\text { Ratio } \\
\text { (A) / (B) }\end{array}$ \\
\hline \multicolumn{7}{|l|}{ CPP } \\
\hline Austria & 0.225 & 0.019 & 11.6 & 0.230 & 0.017 & 13.5 \\
\hline Denmark & 0.170 & 0.019 & 9.0 & 0.170 & 0.008 & 21.3 \\
\hline Finland & 0.187 & 0.018 & 10.5 & 0.210 & 0.013 & 16.2 \\
\hline France & 0.329 & 0.019 & 17.1 & 0.200 & 0.006 & 33.3 \\
\hline Germany* & 0.354 & 0.014 & 25.3 & 0.240 & 0.008 & 30.0 \\
\hline Italy & 0.289 & 0.030 & 9.8 & 0.230 & 0.009 & 25.6 \\
\hline Mexico & 0.115 & 0.030 & 6.7 & 0.403 & 0.026 & 7.7 \\
\hline Netherlands & 0.345 & 0.017 & 20.4 & 0.180 & 0.009 & 20.0 \\
\hline Sweden & 0.256 & 0.012 & 21.9 & 0.220 & 0.008 & 27.5 \\
\hline United Kingdom & 0.204 & 0.009 & 23.2 & 0.160 & 0.005 & 32.0 \\
\hline Average & & & 15.5 & & & 22.7 \\
\hline \multicolumn{7}{|l|}{ MPP } \\
\hline Canada & NA & NA & NA & NA & 0.007 & 0.0 \\
\hline Hong Kong & NA & NA & NA & 0.008 & 0.008 & 1.0 \\
\hline United States** & 0.023 & 0.023 & 1.0 & 0.020 & 0.020 & 1.0 \\
\hline Average & & & 1.0 & & & 1.0 \\
\hline
\end{tabular}

Sources: For 1999 rates, see MOBILE PRICNG STRUCTURES, supra note 159, at 85 tbl. 16 (May 16, 2000). For 2000 rates, see RoHAN SAMARAJIVA \& William H. MELODY, INT'L TELECOMMS. UNION, FIXED-MOBILE INTERCONNECTION WORKSHOP BRIEFING PAPER 11 fig.5, 13 fig.6 (Sept. 14, 2000), available at http://www.itu.int/osg/spu/ni/fmi/workshop/FMI_Briefing_Finall.doc. For rates from Mexico, see OECD, Mobile Cellular Pricing and Trends, Mexico Case Study (April 2000), available at $\mathrm{http}: / \mathrm{www}$.itu.int/osg/sec/spu/ni/fmi/case_studies/index.html.

* MTRs are not regulated in Germany.

** 0.023 represents an average of the rates charged in the United States, according to the OECD table. As of February 2003, the mobile termination rate in the United States had decreased to $\$ 0.005$. See FCC Eighth Annual Report, supra note 19, If 207.

As Table 4 shows, the differences in fixed-to-mobile and mobile-tofixed termination rates among CPP countries greatly exceed the differences in those rates in MPP countries. In 1999, the average ratio of fixed-to-mobile termination rate to mobile-to-fixed termination rate across all CPP countries in Table 4 was 15.5 ; it increased to 22.7 in 2000 . In contrast, the average ratio of fixed-to-mobile termination rate to mobile-to- 
fixed termination rate across MPP countries in our sample for which data were available remained constant at 1.0 from 1999 to 2000 .

Regulators have deprived European fixed-network operators of any countervailing bargaining power vis-à-vis MNOs in setting termination rates, and it is not surprising that European MNOs respond rationally by exploiting this regulatory asymmetry. TeleGeography, a telecommunications consultancy, has noted this asymmetric regulation of fixed and mobile networks in its 2001 study of international mobile traffic:

Regulators in more developed economies, particularly Europe, have focused more on the market power of fixed line operators, requiring those with significant market power (SMP) to offer mobile operators access [to] their networks at cost-based prices. Unsaddled by regulatory constraints, mobile operators have, in turn, been able to charge fixed-line operators access fees well above the fixed-mobile interconnection rate. ${ }^{212}$

Ironically, the European approach is to eliminate asymmetric regulation by piling regulation on competitive carriers. The regulation of mobile-to-fixed termination rates has thus preordained the regulation of fixed-to-mobile termination rates. Rather than layer one form of price regulation on another, regulators in CPP countries should create regulatory parity by deregulating fixed-line operators insofar as their access negotiations with MNOs are concerned.

\section{Conclusion}

MPP is the better option for pricing mobile calls because it aligns the incentives of MNOs and mobile customers, thereby reducing the total cost of using a mobile phone. The experience in the United States and Canada demonstrates that MPP leads to greater use of mobile phones and lower mobile prices. Although mobile penetration in MPP countries was less than the penetration rates in CPP countries in 2003, the growth of mobile penetration in MPP countries suggests that the "penetration gap" will quickly vanish. In the United States, fixed-to-mobile termination rates are not only low but also are roughly equal to mobile-to-fixed termination rates because reciprocal compensation arrangements are permitted.

If regulators are not willing to embrace MPP, then CPP without price regulation is a second-best solution. In particular, MNOs would have incentives to lower mobile termination rates if CPP were combined with (1) mandatory disclosure of termination rates to customers of fixed networks at the time a call is placed; (2) imposition of dedicated number prefixes for MNOs (which is mutually exclusive with number portability);

212 TELEGEOGRAPHY, INTERNATIONAL MoBile TrafFic 2001, at 83 (2002). 
(3) mandatory disclosure of termination rates to a mobile customer upon activation of his account and on his monthly bill; and (4) elimination of mobile-to-fixed termination rate regulation in favor of negotiation between fixed and mobile operators.

The belief on the part of some NRAs that a reasonable termination rate must equal the marginal cost of termination ignores the significant role of fixed and common costs in a mobile network. The measurement problems, perverse incentives for investment, and strategic behavior that have accompanied the use of TELRIC pricing of unbundled network elements in the United States give no reason to believe that regulated, TELRICbased rates would be more accurate, more efficient, and less contentious in the context of mobile termination. Similarly, the belief that a reasonable markup over marginal cost for termination must equal the markup over marginal cost for all other services rests on incorrect economic analysis. With the appropriate market design, there is a good chance that MNOs acting in their own interests, or negotiating with fixed operators, will select the socially optimal fixed-to-mobile termination rate. 

